\title{
tert-AMINO EFFECT: THE METH-COHN AND REINHOUDT REACTIONS (REVIEW)
}

\section{A. Yu. Platonova ${ }^{1}$, T. V. Glukhareva ${ }^{1}$, O. A. Zimovets ${ }^{1}$, and Yu. Yu. Morzherin ${ }^{1 *}$}

The data published over the last 15-20 years on reactions taking place by the tert-amino effect mechanism have been reviewed.

Keywords: nitrogen-containing heterocycles, spiro heterocycles, tert-amino effect, cyclization.

The term "tert-amino effect" was proposed in 1972 [1] for the cyclization reactions of tertiary anilines containing various double bonds at the ortho position. Meth-Cohn and Suschitzky [1] referred to the first observation of the tert-amino effect by Pinnow in 1895 [2]. Many different examples of reactions involving the tert-amino effect have now accumulated, and it clearly is a convenient method for the synthesis of an impressive number of nitrogen-containing heterocycles that otherwise might be difficult to obtain. Reviews were published by Reinhoudt in 1990 [3] and by Meth-Cohn in 1996 [4] on heterocyclization reactions that take place by the mechanism of the tert-amino effect. Another review dedicated to 1,6- and 1,8-naphthiridine derivatives was published in 2003 by Quintela [5]. In the review [6] that we published in 2005, attention was focused on the use of such reactions for the synthesis of spiro compounds. In the review [7], published in 2006, the cyclization reactions of ortho-vinylanilines and their heterocyclic aza analogs were considered, and classification according to the method of ring formation was proposed.<smiles>CCN(CC)c1ccccc1I=O</smiles>
Type 1

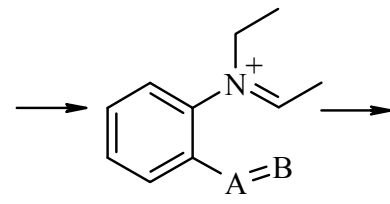

Type 5<smiles>CCN(CC)c1ccccc1I=[In]</smiles>
Type 2<smiles>CCN1c2ccccc2[Y]=Bc2ccccc2C1C</smiles>

Type 3<smiles>B=[Y]1c2ccccc2N(C)c2ccccc21</smiles>

Type 6<smiles>CCN(CC)c1ccccc1[Tl]=[In]C</smiles>

Type 4<smiles>[X]C1CCN(c2ccccc2I=P)CC1</smiles>

Type 7

*To whom correspondence should be addressed, e-mail: yu.yu.morzherin@ustu.ru.

${ }^{1}$ Ural Federal University named after the First President of Russia B. N. Yeltsin, 19 Mira St., Yekaterinburg 620002, Russia.

Translated from Khimiya Geterotsiklicheskikh Soedinenii, No. 3, pp. 386-415, March, 2013. Original article submitted September 5, 2012. 
The term "tert-amino effect" is generally used to describe the cyclization of conjugated $\mathrm{N}, \mathrm{N}$-disubstituted amines, where the key stage is hydrogen transfer from an unactivated $\alpha$-carbon atom of an amino group to one of the atoms of a double bond.

It is worth noting that various names have been used for this reaction in the literature: reactions occurring by the tert-amino effect mechanism; intramolecular redox process; 1,5(1,7)-hydride shift; reactions at unactivated $\alpha$-carbon atom; the "Twente variant" of the tert-amino effect; redox-neutral $\mathrm{C}-\mathrm{H}$ bond functionalization; T-reactions; redox/1,5-hydride shift/cyclization; asymmetric $s p^{3} \mathrm{C}-\mathrm{H}$ functionalization, etc. In our opinion the traditional nomenclature (named reactions) should be used: cyclization of $N, N$-disubstituted anilines (heterocyclic amines) that contain unsaturated ortho-substituents with at least one heteroatom (nitroso, nitro, azo, azomethino, amino, or carbonyl groups) is the Meth-Cohn reaction [1,4]; reaction of amino derivatives with an ortho-vinyl group leading to the formation of a new carbon-carbon bond is the Reinhoudt reaction [3].

In this review we consider examples of the Meth-Cohn and Reinhoudt reactions published over the last 15-20 years. Special attention is paid to the formation of carbon-carbon bonds.

\section{Reinhoudt Reaction}

The first example of such a reaction is the rapid thermal cyclization of tertiary anilines containing a dicyanovinyl group at the ortho position, which is a reaction of type 2 by this classification [8]. The cyclization mechanism proposed by Reinhoudt's group is based on kinetic investigations and on the use of a deuterium label [9]. It is illustrated for the case of [2-(pyrrolidin-1-yl)benzylidene]malonodinitriles $\mathbf{1}$ and was presented in a review [3].

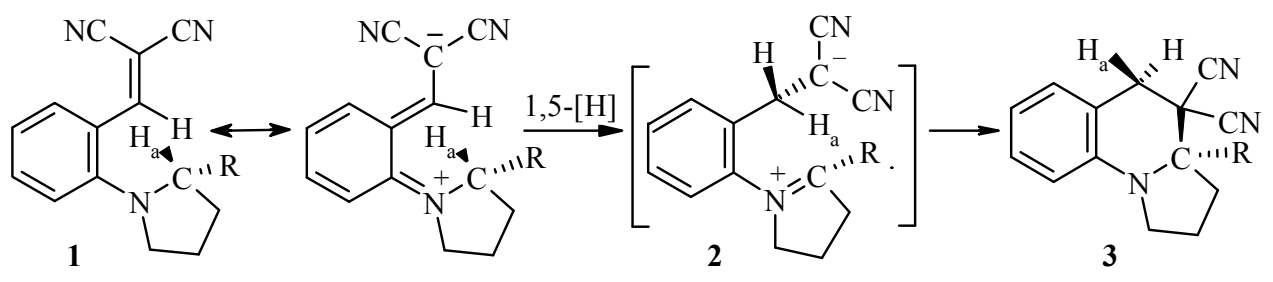

The controlling stage includes the migration of hydrogen in a conformation, in which the vinyl group is separated from the amino group, and leads to a dipolar intermediate 2. The migrating hydrogen atom $\left(\mathrm{H}_{\mathrm{a}}\right)$ stays on the same side of the molecule. Subsequently, rotation occurs about the $\sigma$-bond with the phenyl substituent, and a new $\sigma$-bond is formed between the two oppositely charged carbon atoms, leading to a new six-membered ring 3. It was shown that a $\mathrm{C}-\mathrm{C}$ bond is formed from the side of the leaving proton $\mathrm{H}_{\mathrm{a}}$, i.e., the configuration at the asymmetric $\alpha$-carbon atom of the dialkylamino group is preserved. During examination of the first stage mechanism, both [1,5]-sigmatropic (a synchronous process) and 1,5-hydride (a two-stage process) shifts were discussed. The stereochemical features of this rearrangement, including enantio- and diastereoselectivity, can be reconciled well both with a sigmatropic and with an ionic mechanism of migration.

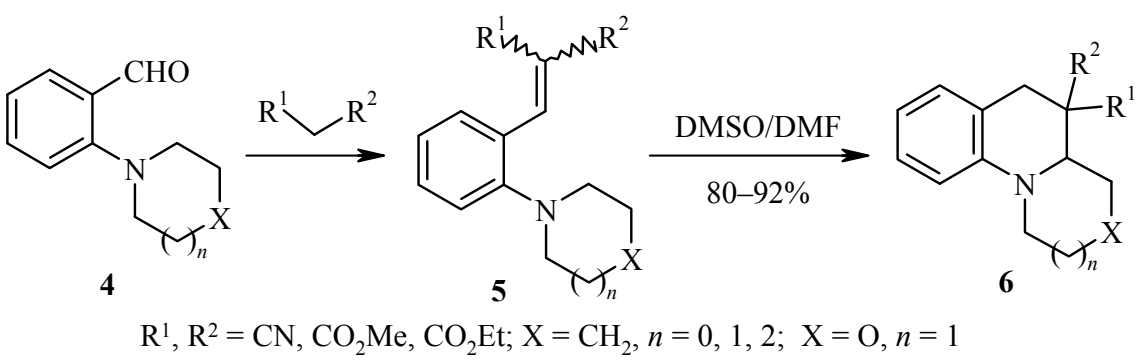


The effect of the structure of the amino group and the vinyl substituent on the cyclization has been well studied and described for the benzaldehyde derivatives 4. It was shown that the vinyl derivatives $\mathbf{5}$ underwent cyclization to quinolines $\mathbf{6}$ not only thermally [10], but also under microwave treatment [11] and electron impact [12].

Professor Reinhoudt's group established the criteria for the occurrence of a type 2 cyclization (see p. 357). A systematic study of the effect of substituents in the ortho-vinyl group of dialkylanilines 7 [13-15] showed that cyclization in the case of an electron-withdrawing group at the $\alpha$-position of the vinyl function $\left(\mathrm{R}^{1}\right)$ led to the formation of five-membered rings 8 (a type 1 cyclization). Compounds having two electronwithdrawing groups at the $\beta$-position of the vinyl function $\left(\mathrm{R}^{2}\right.$ and $\left.\mathrm{R}^{3}\right)$ formed six-membered rings 9 (a type 2 cyclization). If there was only one electron-withdrawing group at the $\beta$-position of the vinyl group $\left(R^{2}=H\right)$, the reaction did not occur.

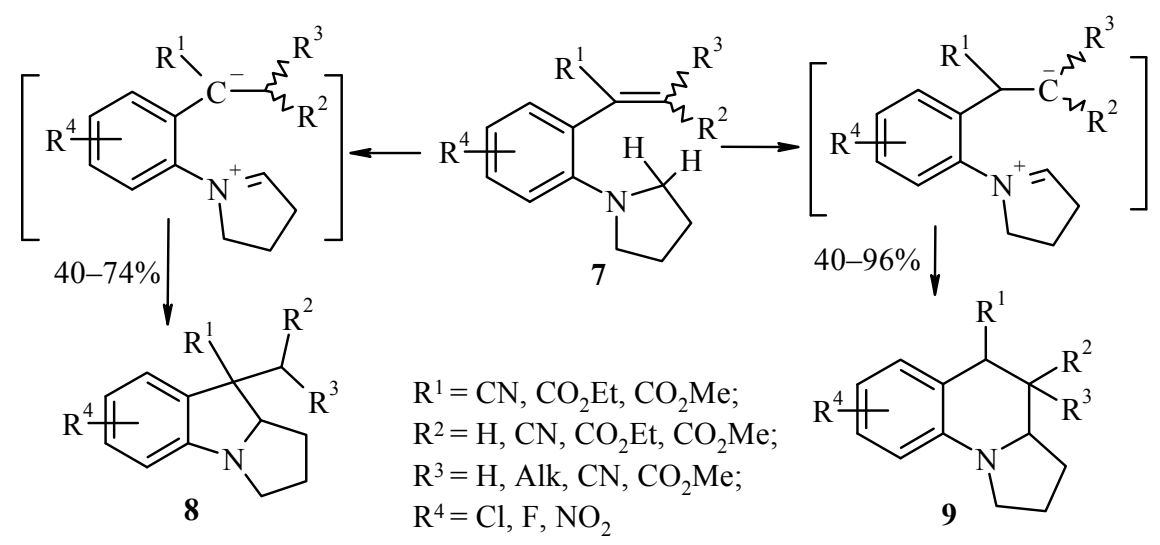

The synthesis of isoquinolino[2,1-a]quinoline 10, isoindolo[2,1-a]quinoline 11, and indolo[2',3':3,4]pyrido[1,2-a]quinoline 12 (in 70-90\% yields) was similar to the synthesis of compound $\mathbf{5}$ with the exception that simple amines were replaced by more complicated ones, such as 1,2,3,4-tetrahydroisoquinoline, 2,3-dihydro$1 H$-isoindole, and 1,2,3,4-tetrahydro-9H-pyrido[3,4- $b]$ indole. Reactions in which secondary amines of natural origin [16] and chiral bicyclic amines [17] were used have also been described.<smiles>N#CC1(C#N)Cc2ccccc2N2CCc3ccccc3C21</smiles>

10<smiles>N#CC1(C#N)Cc2ccccc2N2Cc3ccccc3C21</smiles>

11<smiles>N#CC1(C#N)Cc2ccccc2N2CCc3c([nH]c4ccccc34)C21</smiles>

12

It is not only tertiary anilines with an ortho-vinyl group that can be cyclized by the mechanism of the tert-amino effect. The cyclizations of tertiary amines of pyridine $\mathbf{1 3}$ have been described [18, 19]. We consider it necessary to mention two unexpected paths of ring closure that emphasize the important role of the tertiary amino group in cyclization by the mechanism of the tert-amino effect.<smiles>CCOc1nc(N2Cc3ccccc3C2)c(/C=C(/P)C#N)c(C#N)c1-c1ccccc1</smiles>

13

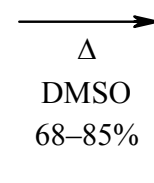

$n=1,2$<smiles>CCOc1nc2c(c(-c3ccccc3)c1C#N)CC(C#N)(C#N)C2c1ccccc1Cl</smiles>

14 
The first example represents the anomalous reactions observed with the indoles and quinolines 15a-d [18]. Compounds 13 and 15a-d underwent cyclization in different ways. It was found that upon thermal cyclization of the pyridines $\mathbf{1 3}$ the reaction followed exclusively the tert-amino effect mechanism; the corresponding tetracyclic compounds $\mathbf{1 4}$ were isolated, whereas the pyridines 15a-d containing a less basic nitrogen atom in the amino group [18] gave the conjugated cyclic systems 16a-d by successive electrocyclization-aromatization.

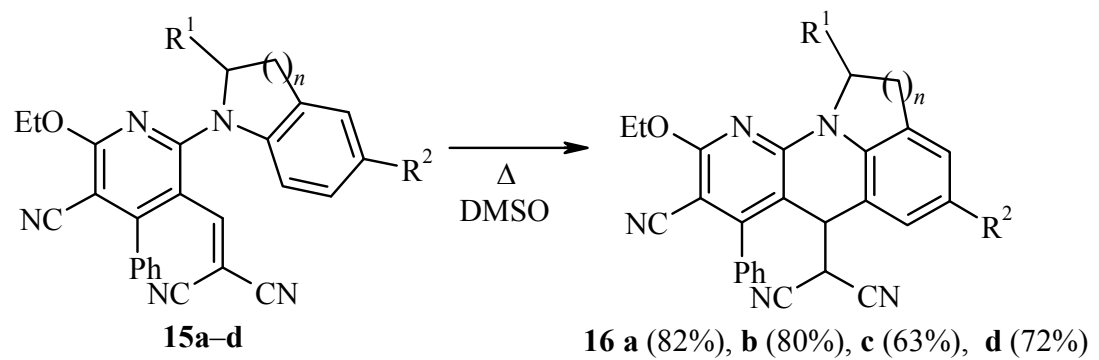

$$
\mathbf{a} n=1, \mathrm{R}^{1}=\mathrm{R}^{2}=\mathrm{H} ; \mathbf{b} n=2, \mathrm{R}^{1}=\mathrm{R}^{2}=\mathrm{H} ; \mathbf{c} n=1, \mathrm{R}^{1}=\mathrm{Me}, \mathrm{R}^{2}=\mathrm{H} ; \mathbf{d} n=2, \mathrm{R}^{1}=\mathrm{Me}, \mathrm{R}^{2}=\mathrm{F}
$$

The second example describes ring closure in the 4-amino-3-vinylpyridine derivatives 17, obtained from 3-bromopyridine-4-carbaldehyde [19]. It was shown that cyclization of the piperidine derivative 17a led to the expected product 18a. However, heating of the 4-piperazino-, 4-morpholino-, or 4-thiomorpholino-3-vinyl pyridine derivatives $\mathbf{1 7} \mathbf{b}-\mathbf{d}$ in DMSO solution led to a product mixture containing not only the pyridopyridines 18b-d but also the tricyclic azepines 19b-d.

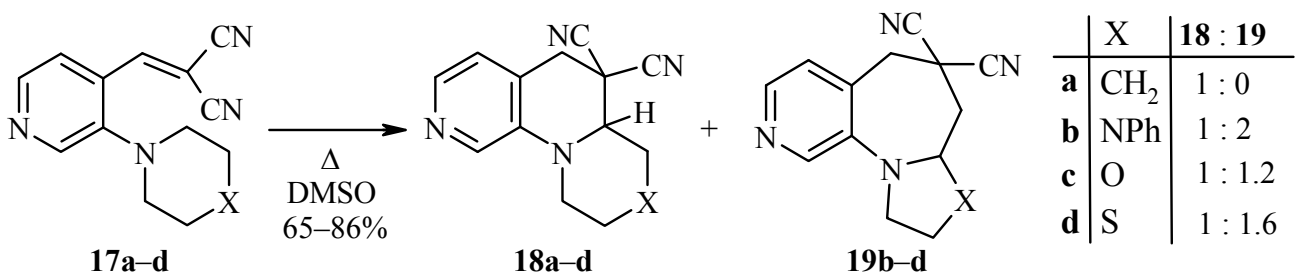

The formation of the products $\mathbf{1 9 b}$-d was explained by the presence of the intermediate $\mathbf{2 0}$, which was formed by a 1,5-sigmatropic shift from the vinyl derivative 17. Cyclization of compounds $\mathbf{1 7}$ could lead to the tetrahydropyridines $\mathbf{1 8}$ through the formation of the imine $\mathbf{2 0}$. If there was a heteroatom $(X=N, O, S)$ in the cycloalkylamine, then generation of the isomeric structure $\mathbf{2 1}$ was possible, where cyclization could lead both to the six-membered heterocycles $\mathbf{1 8}$ and to the azepines 19.

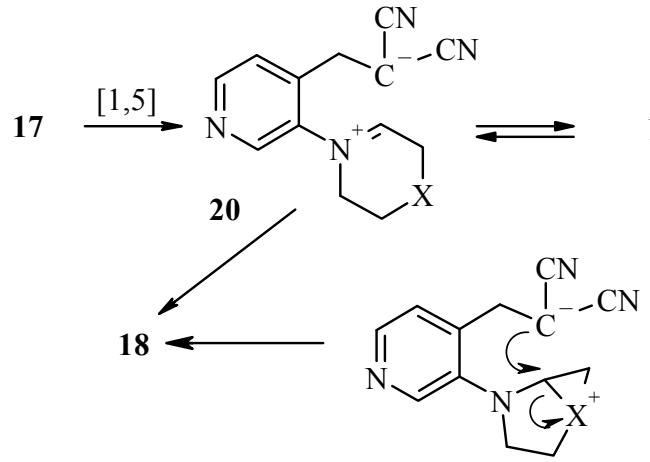

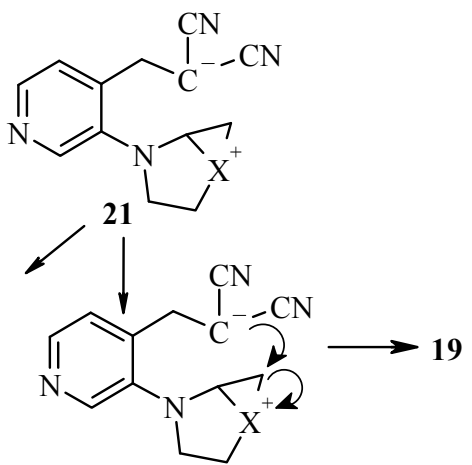


Thermal cyclization by the tert-amino effect mechanism was also typical for the diazine derivatives 22a-e. Like the previously mentioned ortho-vinylanilines 5 and ortho-vinylpyridylamines 17, the 6-amino5-vinyluracil derivatives 22a-e underwent cyclization when heated in toluene in the presence of $\mathrm{ZnCl}_{2}$; the pyrido[2,3- $d]$ pyrimidines 23a-e were formed as a result. The yields were usually very low under these conditions (3-29\%), while the pyrrolidine derivatives 22a hardly reacted at all [20]. However, under different reaction conditions, in refluxing $n$-butanol [21] or DMSO at $140^{\circ} \mathrm{C}$, cyclization of some of these uracil derivatives 22a-e gave higher yields (67-87\%).

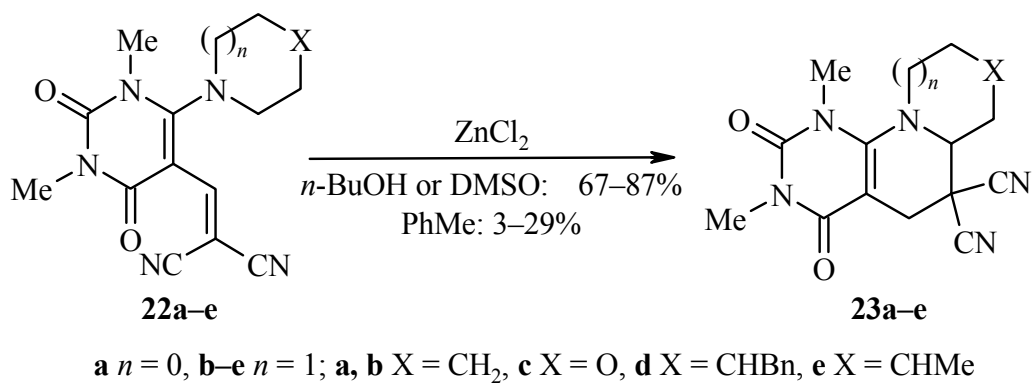

During the cyclization of aromatic derivatives of pyrimidines 24 and 25a-c, which have tert-amino- and dicyanovinyl groups at neighboring positions, two types of cyclic systems were formed depending on the structure of the tert-amino group. From compounds 24a-c, containing an alicyclic tert-amino group, the tricyclic products 26a-c were formed by the the tert-amino effect mechanism. The alkenes 25a-c, in which the the amino group nitrogen belonged to an indole or quinoline, were transformed into the tetracycles $\mathbf{2 7} \mathbf{a}-\mathbf{c}$, the formation of which can include electrocyclization, similar to the pyridine analog 16 formation from the olefin 15 [22].

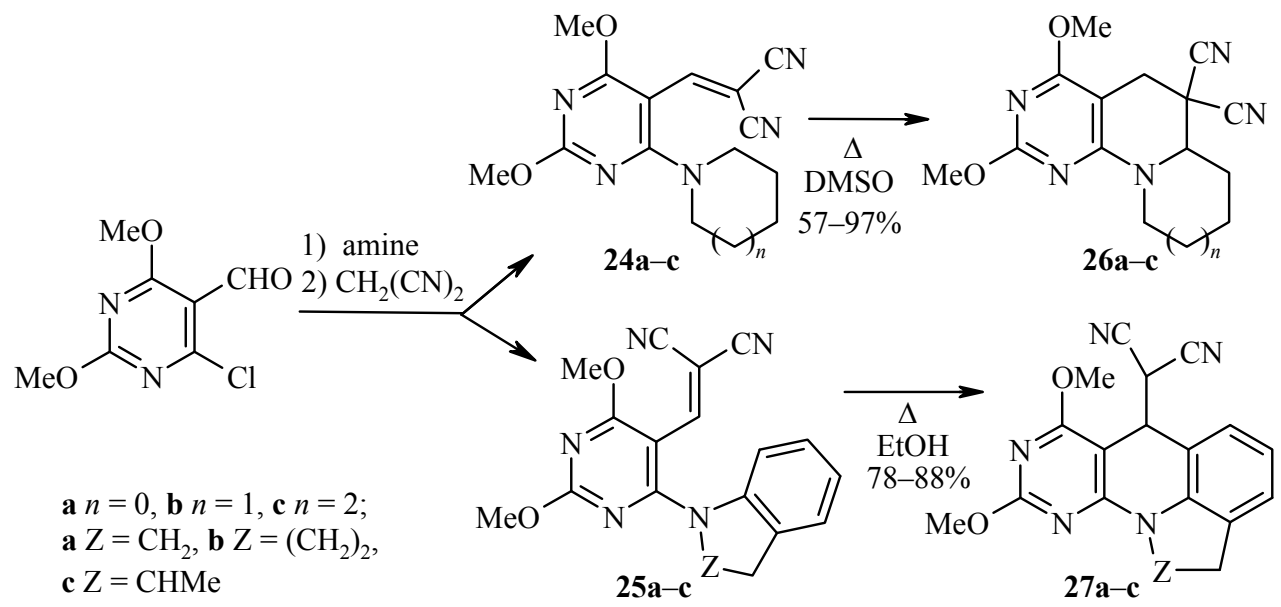

The first report on using the tert-amino effect for the synthesis of conjugated cyclic pyridazine systems appeared more than 15 years ago [23]. The synthesis was based on the cyclization of pyridazin-3(2H)-ones 29a-c containing vinyl and tert-amino groups, which were obtained in two stages from 5-dialkylaminopyridazinones 28. The prolonged heating of compounds $\mathbf{2 9 b}, \mathbf{c}$ in DMSO at $150^{\circ} \mathrm{C}(39-44 \mathrm{~h})$ led to the formation of tricyclic compounds 30b,c with yields of 35-44\%. Cyclization of compound 29a did not occur in refluxing butanol [24].

All the aforementioned cyclization examples assume that strong electron acceptors at the terminal carbon atom of the vinyl group are required for cyclization. Indeed, two cyano groups can be considered the optimal substituents for ring closure, as was demonstrated for the case of the relatively unreactive heterocyclic analogs of tertiary anilines. 


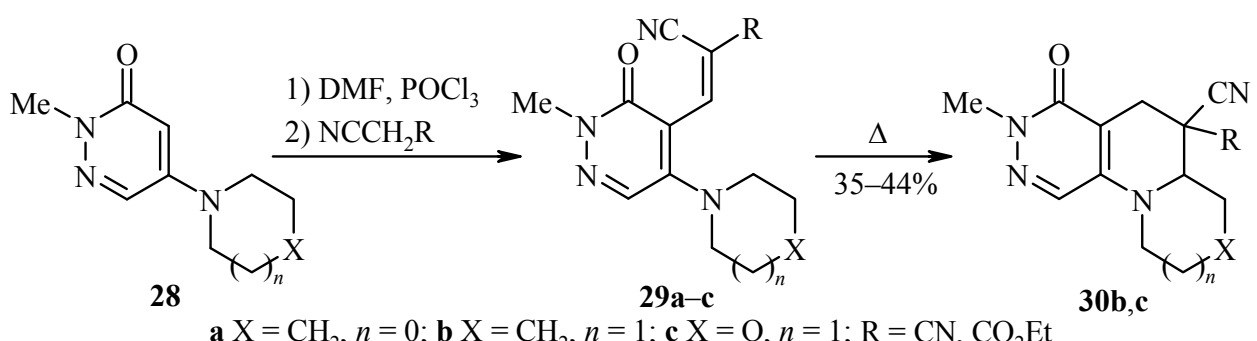

Most of the cyclization substrates had two cyano or ester groups at the terminal carbon atom of the vinyl group. The cyclization reactions of compounds with two different substituents at the $\beta$-carbon atom of the vinyl group have been studied to a much lesser degree. We showed [25] that the cyclization of thioamide 31b led to the $\left(4 \mathrm{a} R^{*}, 5 R^{*}\right)$-isomer $\mathbf{3 2} \mathbf{b}$, whereas the amide 31a did not undergo cyclization under such conditions. It should be noted that compound 32b contains two asymmetric centers, and the formation of two diastereomers is therefore possible. It was shown that the reaction was stereoselective and formation of one diastereomer was favored (de 95-98\%). It should be noted that the reaction of the benzaldehyde $4 \mathbf{n}$ with cyanothioacetamide in butanol occurred in one stage, forming the tricyclic compound 32b. The cyclization of the amides 31a required a Lewis acid catalyst $\left(\mathrm{ZnCl}_{2}\right)[26]$.

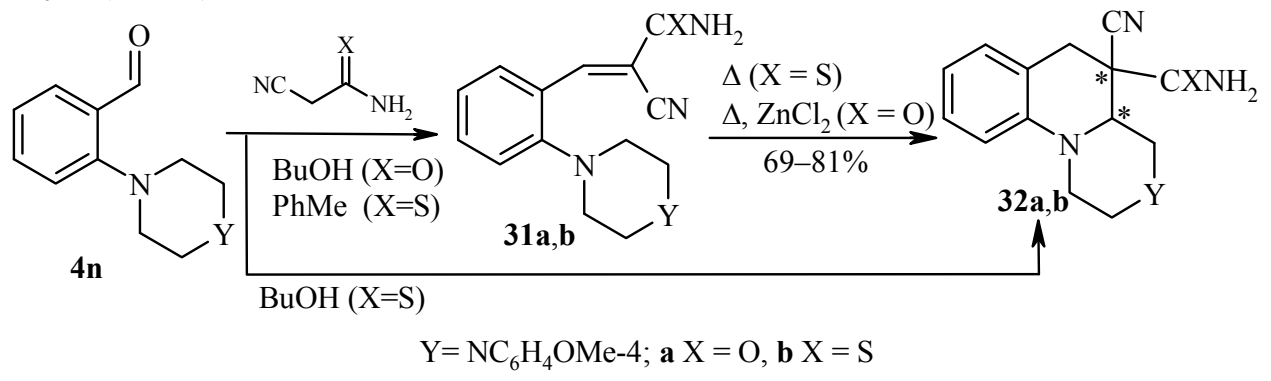

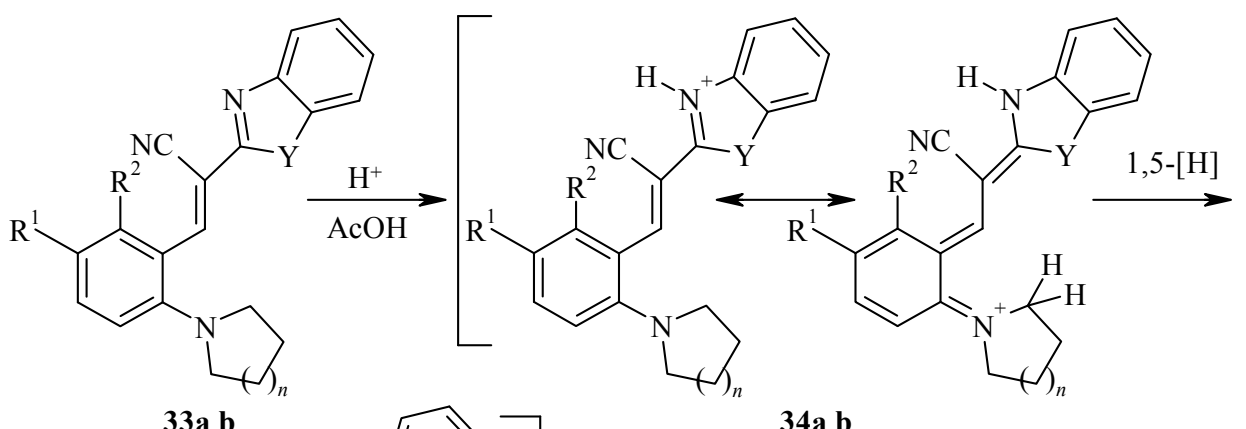

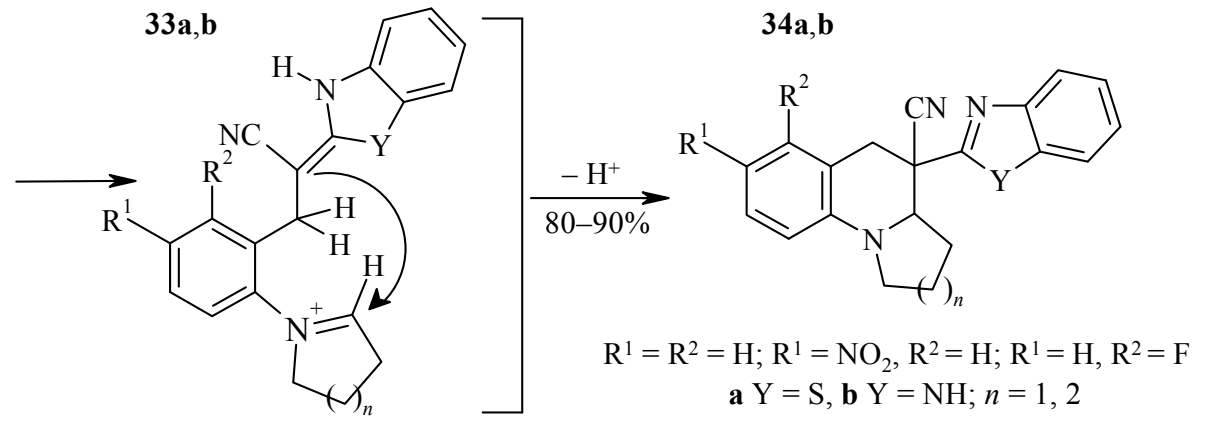

Tverdokhlebov [27] and Ryabukhin [28] studied the cyclization of benzothiazoles 33a and benzimidazoles $\mathbf{3 3 b}$. It was found that the reaction was facilitated by acid catalysis. The authors explained this by protonation at the nitrogen atom of the heterocycle and formation of the structure 34 . 
The first example of spiro-coupled heterocycle synthesis by the tert-amino effect mechanism was published in 2000 [10]. In spite of the electron-deficient pyrimidine ring, the reaction with cyclic active methylene components was shown to increase the rate of compound $\mathbf{3 6}$ cyclization to the spirocyclic systems 37.

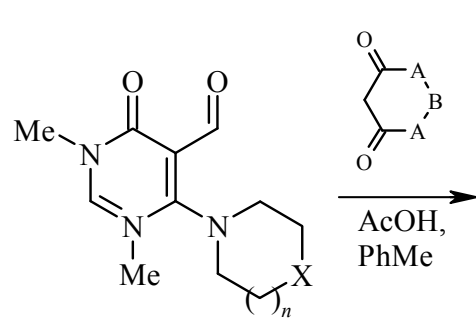

$35 \mathbf{a}-\mathbf{c}$ a $\mathrm{A}=\mathrm{NMe}, \mathrm{B}=\mathrm{C}=\mathrm{O}, \mathrm{X}$<smiles>[Y]CCN1c2c(c(=O)n(C)c[n+]2C)CC2(CC[IH]NC2=O)C1C[Y]</smiles>

$37 \mathbf{a}-\mathbf{c}$

$$
\text { c } \mathrm{A}=\mathrm{B}=\mathrm{X}=\mathrm{CH}_{2}, n=1
$$

The use of the tert-amino effect for the synthesis of new spirocyclic conjugated pyridodiazines [29-31] was quite effective, in that the vinyl derivatives 36a-c could be easily obtained by Knoevenagel condensation of pyrimidine aldehydes 35a-c with $N, N$-dimethylbarbituric acid or Meldrum's acid. Compounds 36a-c underwent transformation with remarkable ease, providing access to the corresponding tetrahydropyridines 37a-c with spirocyclic substituents. In fact, compounds 36a-c cyclized at a lower temperature and more quickly than the dicyanovinyls 29a-c.<smiles>[R]c1cc(C=O)c(N(C)CC([R])[X])c([R])c1[R]</smiles>

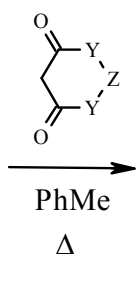<smiles>[Y]C(=O)/C(=C/c1cc([R])c([R])c([R])c1N(CCC)CC([R])[R])C([Y])[X]</smiles><smiles>[Y][Y](=O)C1(C([Y])=O)Cc2cc([R])c([R])c([R])c2N(CC([R])[R17])C1C([R])[X]</smiles>

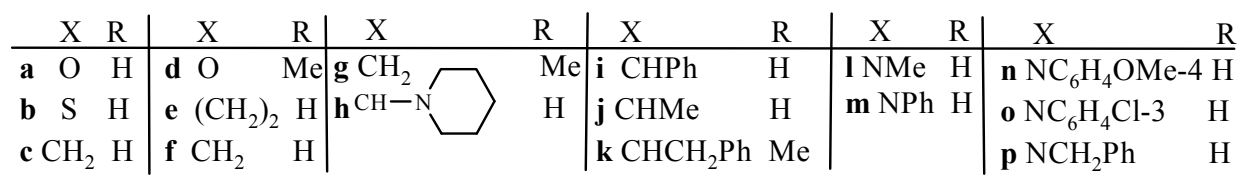

$\mathbf{a}, \mathbf{b}, \mathbf{d}-\mathbf{p} n=1, \mathbf{c} n=0$

$\mathrm{R}^{1}=\mathrm{R}^{3}=\mathrm{H}, \mathrm{R}^{2}=\mathrm{H}, \mathrm{Cl}, \mathrm{Br}, \mathrm{F} ; \mathrm{R}^{1}=\mathrm{R}^{2}=\mathrm{H}, \mathrm{R}^{3}=\mathrm{Br}, \mathrm{F}, \mathrm{CF}_{3} ; \mathrm{R}^{1}=\mathrm{F}, \mathrm{R}^{2}=\mathrm{R}^{3}=\mathrm{H}$ $\mathrm{X}=\mathrm{CO}, \mathrm{Y}=\mathrm{NMe} ; \mathrm{X}=\mathrm{CMe}_{2}, \mathrm{Y}=\mathrm{O} ; \mathrm{X}=\mathrm{Y}=\mathrm{CH}_{2}, \mathrm{Y}=\mathrm{CMe}_{2}, \mathrm{X}=\mathrm{CH}_{2}$

On the basis of X-ray structural analysis data [30], the authors concluded that the more sterically hindered starting compounds underwent faster rearrangement, thus cyclization removed the steric strain. A phenyl group at position 6 of the pyridazine ring also increased the cyclization rate of compound 28. This can be explained by a decrease in the conformational freedom of the neighboring tert-amino group, which promoted migration of the hydrogen and facilitated the ring closure. 
We showed [32-34] that the reaction of cyclic $\mathrm{CH}$ acids with ortho-aminobenzaldehydes 4 took place in one stage with the immediate formation of two $\mathrm{C}-\mathrm{C}$ bonds and led to the spiroheterocycles 38 .

The reaction proceeded similarly in the case of thiobarbituric acid [35-37]. The authors also demonstrated that condensation under mild conditions (aqueous ethanol, $50^{\circ} \mathrm{C}, 5 \mathrm{~min}$ [37]) allowed to isolate the intermediate vinyl derivatives 39 with yields up to $86 \%$.

In the case of using the monosubstituted barbituric acids $\mathbf{4 0 a}, \mathbf{b}$, the formation of two isomers was possible. We showed [38] that with the monosubstituted barbituric acid 40b a 1:1 mixture of spiro-coupled

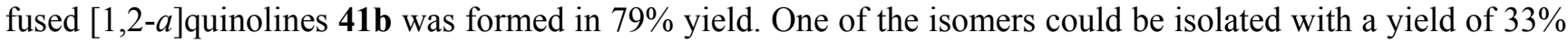
by fractional crystallization from aqueous alcohol.
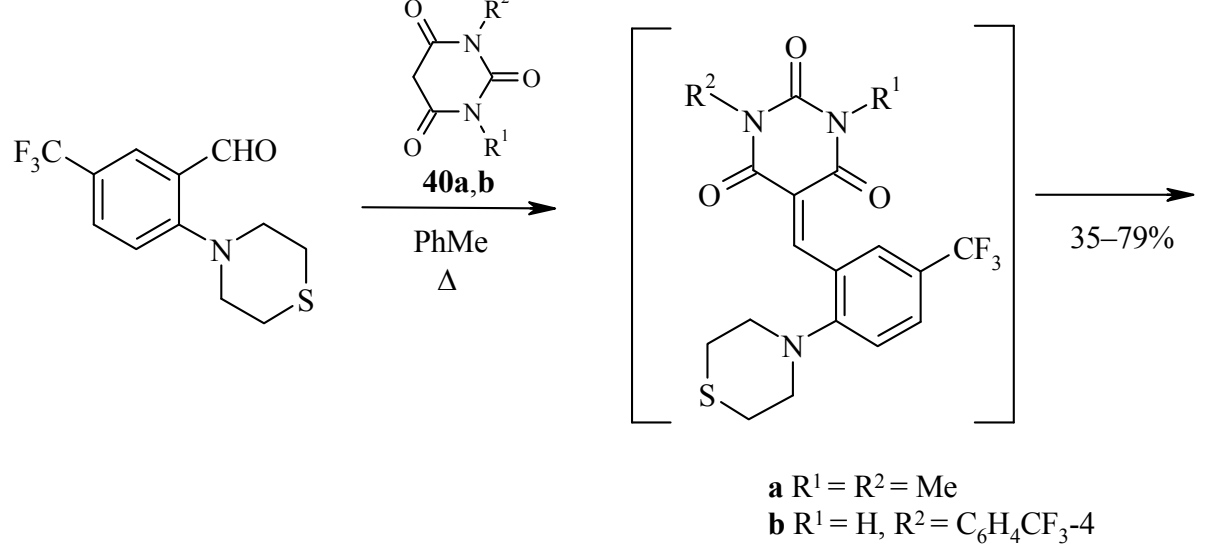<smiles>[R]N1C(=O)N([R])C(=O)C2(Cc3cc(C(F)(F)F)ccc3N3CCSCC32)C1=O</smiles>

We also established [39] that the reaction of 2-(3,5-dimethylpiperidino)benzaldehyde (4g) with Meldrum's acid and cyclohexanedione was stereoselective and led to the formation of only one isomer $\mathbf{4 2 b}$ with the axial arrangement of the hydrogen atoms at positions 4 and $4 \mathrm{a}$ of the pyrido[1,2- $a$ ]quinoline ring, as shown by the spin-spin coupling constant $J=9.7-9.8 \mathrm{~Hz}$ in the ${ }^{1} \mathrm{H}$ NMR spectra of the obtained compounds. It was thus found that the cyclization by tert-amino effect mechanism occurred diastereoselectively when there was a substituent at the $\beta$-carbon atom in the dialkylamino group.

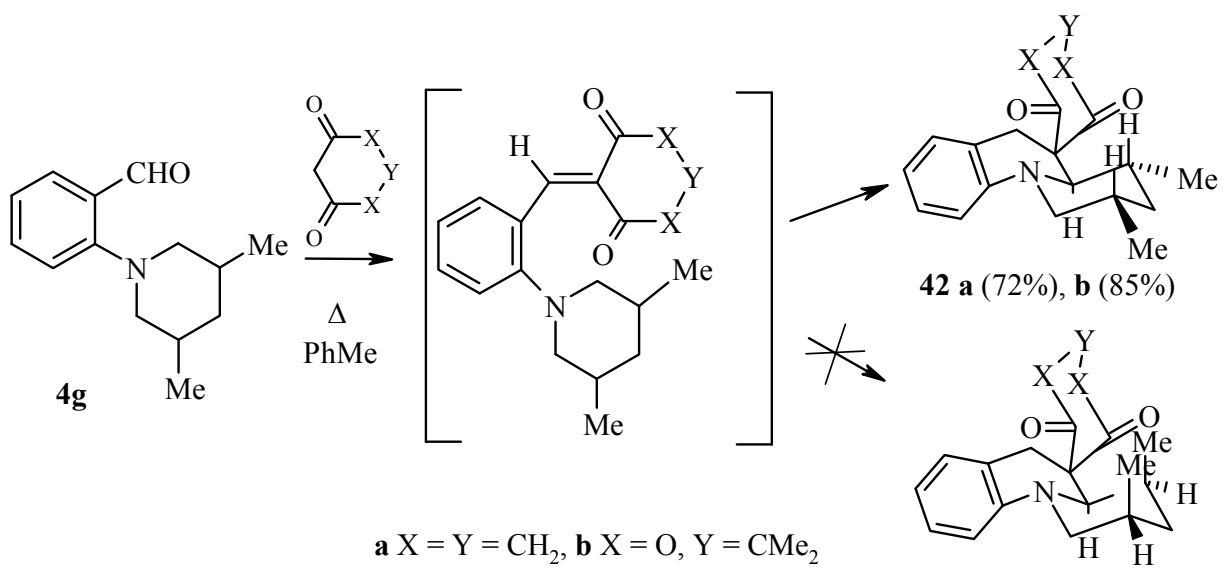

The 2-(4- $R$-piperidino)benzaldehydes 43 selectively cyclized by tert-amino effect mechanism with cyclic activated methylene compounds (Meldrum's acid, 1,3-cyclohexanedione, and $N, N$-disubstituted barbituric acids) with the formation of spiro-coupled 2,3,4,4a,5,6-hexahydro-1H-pyrido[1,2-a]quinolines 44 with axially arranged hydrogen atoms at positions 3 and $4 \mathrm{a}$ of the benzo[c]quinolizine ring [40, 41]. 


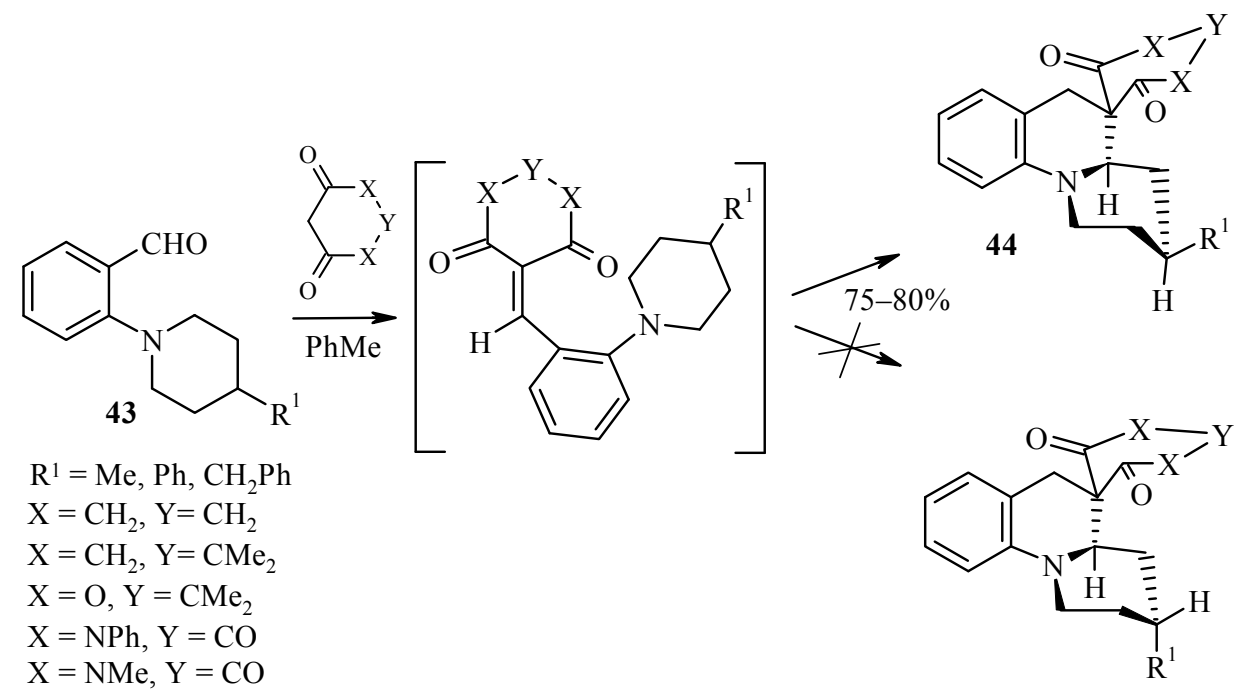

At the same time, the cyclization of the similar derivatives $\mathbf{4 5}$ obtained from a noncyclic methylene component (malonodinitrile) led to the formation of two isomeric products $\mathbf{4 6}$ and $\mathbf{4 7}$ (in a 1:1 ratio) [41].<smiles>[R]C1CCN(c2ccccc2C=C(C#N)C#N)CC1</smiles>

45

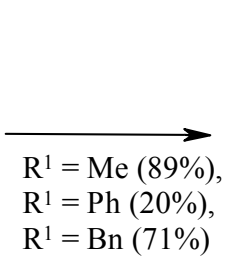

$\mathrm{R}^{1}=\mathrm{Bn}(71 \%)$<smiles>[R]C1CCN2c3ccccc3CC([R])(C#N)[C@@]12C</smiles>

46<smiles>[R]C1CCN2c3ccccc3CC([R])(C#N)[C@@]12C</smiles>

47

The selective course of the cyclization in the case of aldehydes $\mathbf{4 3}$ could be explained by steric factors. During the formation of the intermediate olefin, the double bond was probably turned in such a way that the equatorial proton at the $\alpha$-carbon atom was close to the double bond. It should be noted that the possibility of a $\pi \cdots \mathrm{H}$ bond in such compounds was demonstrated [37], and this explained the low barrier to hydrogen migration from the $\alpha$-carbon atom at the amino group to the double bond carbon atom [42]. Here the substituent at position 4 of the piperidine fragment was located equatorially due to the steric influence of the bulky cyclic substituent at the double bond. A similar effect was not observed in the cyclization of compound $\mathbf{4 5}$, allowing the formation of two isomers 46 and 47 [41].

The authors of works [43-46] studied the reaction of the benzaldehyde 48 with barbituric acid by ${ }^{1} \mathrm{H}$ NMR spectroscopy and suggested a stereochemical path for the reaction. The product $\mathbf{4 9}$ was readily formed at room temperature. The bipolar intermediate $\mathbf{5 0}$ was formed by an intramolecular hydrogen shift. The kinetically controlled product $\mathbf{5 1}$ was formed as a result of axial attack by the enolate on the iminium ion. Compound $\mathbf{5 1}$ further thermally isomerized by a retro-Mannich reaction to the zwitterion 50, which underwent cyclization [45] to the thermodynamically favored product $\mathbf{5 2}$. 
<smiles>CC(O)C(=O)CC(=O)NC(=O)C1CN(c2ccc([N+](=O)[O-])cc2C=O)C[C@@H](C)O1</smiles>

48

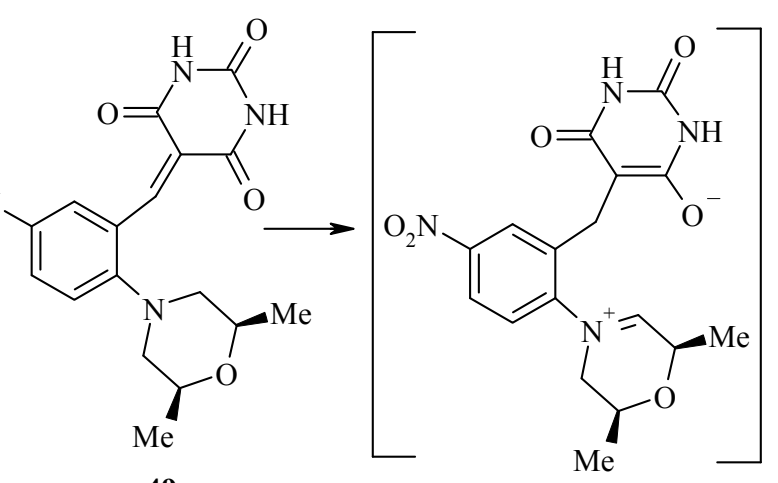

49<smiles></smiles>

$51(74 \%$, er $>99: 1)$

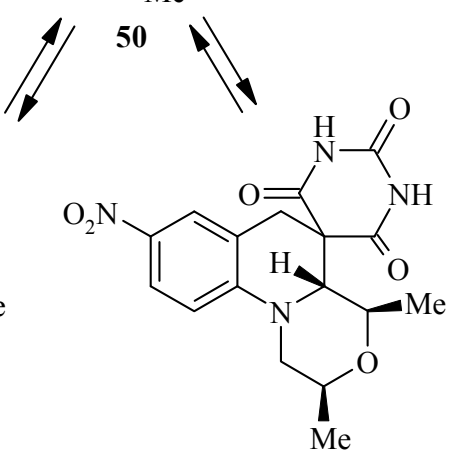

$\mathbf{5 2}(48 \%, e r>99: 1)$

The use of 5-methyl-2-phenylpyrazol-3-one $\mathbf{5 3}$ as the active methylene component $[28,47]$ in the reactions with benzaldehydes 4 led to only one of the two regioisomers of the spiro compounds 54 .

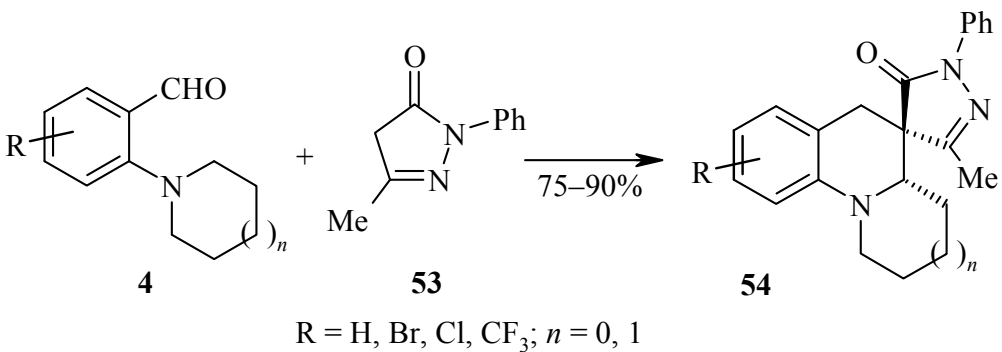

Another approach to the synthesis of the spiro compounds was described by Ukrainian scientists [48]. During the cyclization of compounds $\mathbf{5 5}$ containing methyl and cycloalkyl groups at the nitrogen atom, only the spiro compounds 56 were formed.

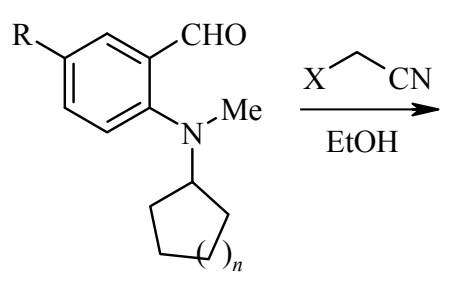<smiles>[X]/C(C#N)=C/c1cc([R])ccc1N(C)C1CCCCC1</smiles><smiles>[R]c1ccc2c(c1)CC([X])(C)C1(CCCCC1)N2C</smiles>

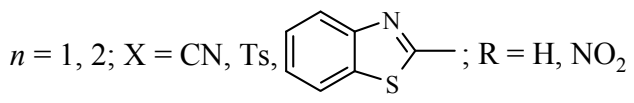


Cyclization by the tert-amino effect of type 2 has also been observed when bicyclic substrates were used; the quinoline derivatives $\mathbf{5 7}$ entered readily into the Reinhoudt reaction [49].<smiles>[R]c1ccc2nc(N3CC[X]CC3)c(C=O)cc2c1</smiles>

57

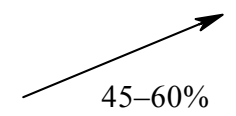

$45-60 \%$

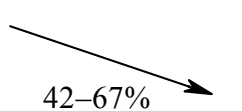

$42-67 \%$

$\mathrm{R}$

$\mathrm{R}=\mathrm{H}, \mathrm{Me}, \mathrm{OMe}$<smiles>[R]c1ccc2nc3c(cc2c1)CC(C#N)(C#N)C1C[X]CCN31</smiles><smiles>[X]CC1N(C)c2nc3ccc([R])cc3cc2CC2(C(=O)N(C)C)CCCCN12</smiles>

An example of the use of the tert-amino effect in coumarin and 2-quinolone systems was described [50]. It should be noted that the Knoevenagel condensation products $\mathbf{5 8}$ underwent cyclization to compounds $\mathbf{5 9}$ in the presence of acetic acid.

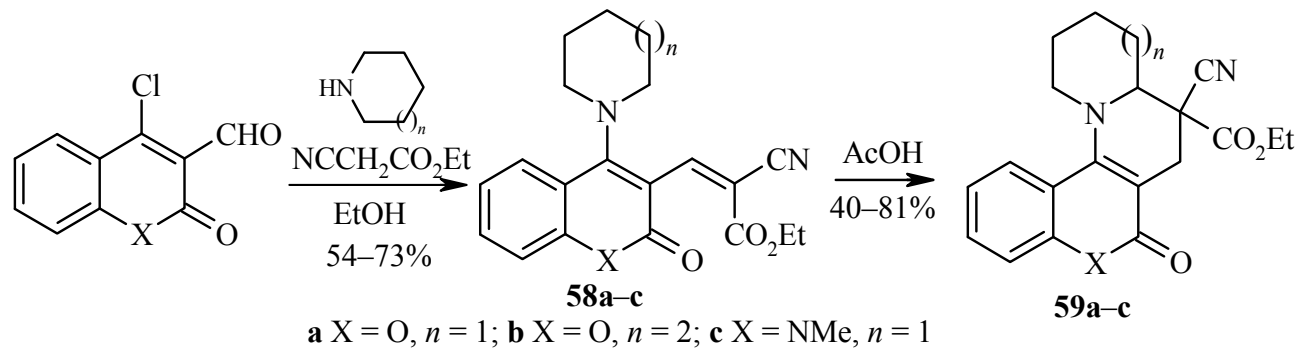

It was shown [51] that compounds 62a-e and 63a-c, obtained from 2-formyl- (60) and 2,7-diformyl1,8-bis-(dimethylamino)naphthalenes (61), cyclized to 1,2,3,4-tetrahydrobenzo[ $h]$ quinolines $\mathbf{6 4 a - e}$ and quino[7,8-h]-quinolines 65a-c, respectively.
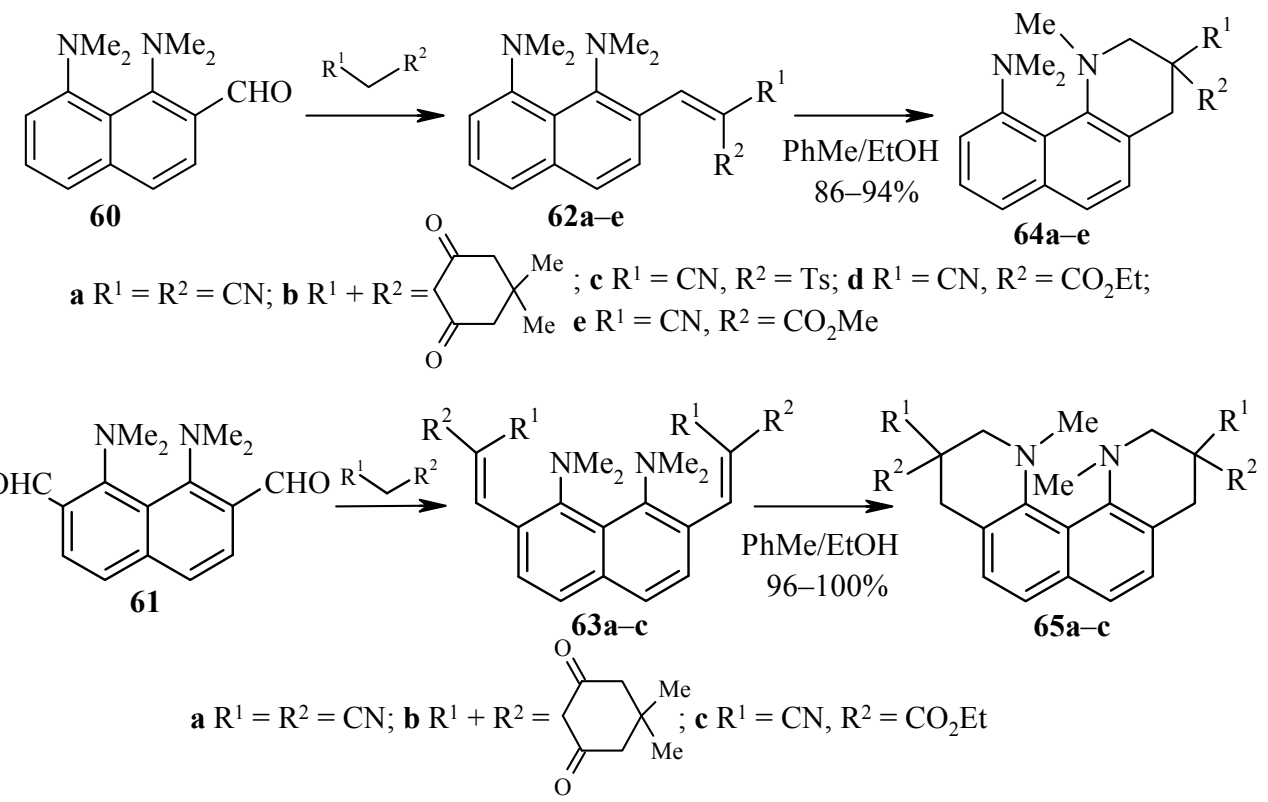
The Reinhoudt reaction is also characteristic of five-membered heterocycles $[6,26,28,30]$ and their fused analogs [53, 54]. Thus, in 5-chloro-3-methyl-1-phenylpyrazole-4-carbaldehyde [26, 28] the chlorine atom was easily substituted by secondary amines. The tertiary amines 66 thus obtained condensed with acyclic [30, 53] or cyclic [6] active methylene compounds (the vinyl derivatives 67 and 68) and yielded the condensed systems 69 and 70.

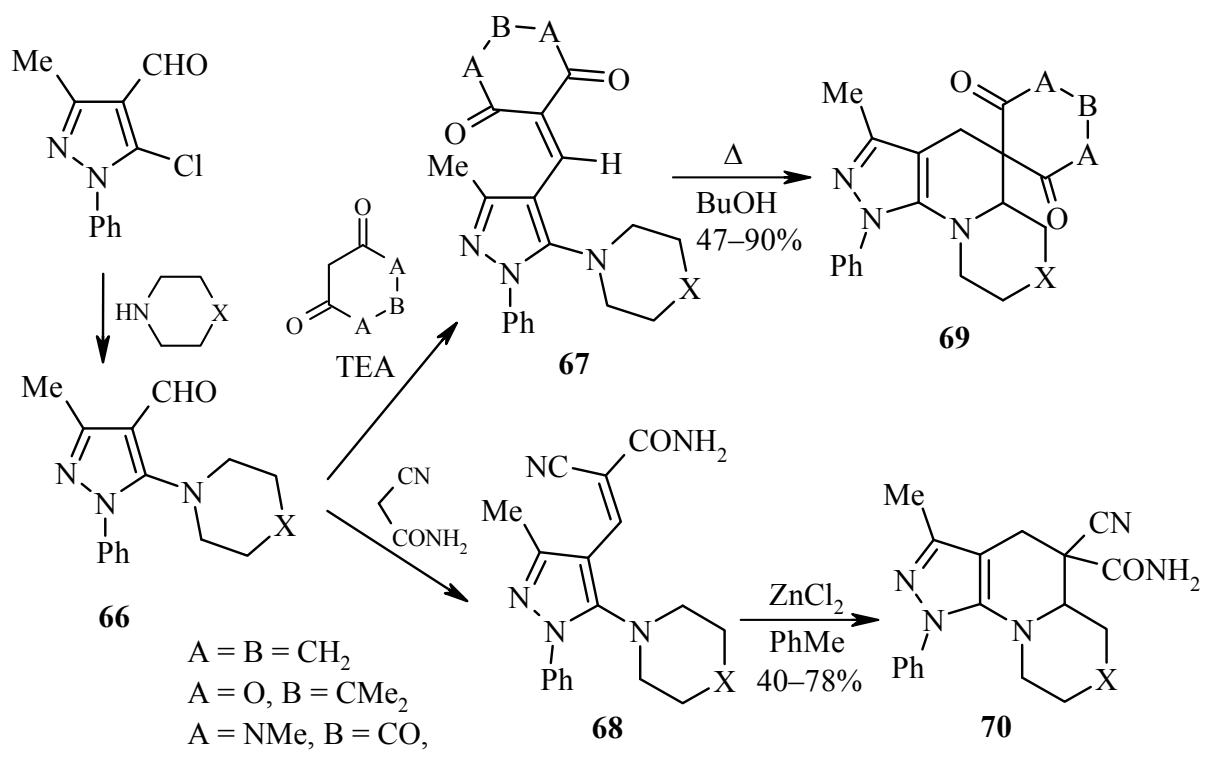

For benzene and pyridazine substrates, ring closure was an exothermic reaction requiring high temperatures. This shows that the method of heat transfer can have particular significance during a thermal cyclization. Accordingly, certain reactions were conducted under the influence of microwave irradiation in order to reduce the reaction time and to prevent or at least reduce the formation of side products $[11,24,31]$.

The cyclization of vinyl derivatives of the aldehyde $\mathbf{4 c}$ under microwave irradiation was investigated. Comparing the results of the reactions, conducted under microwave irradiation conditions, and obtained by the traditional method it was established that the reaction time could be reduced significantly with microwave irradiation, even in those cases where cyclization took several days of heating [11]. In their investigations, the authors used water instead of organic solvents. Compound $\mathbf{6 a}$ was synthesized in water medium with a catalytic amount of trifluoroacetic acid in $3 \mathrm{~min}$ at $200^{\circ} \mathrm{C}$. Cyclization was also achieved by microwave irradiation without a solvent [31]. In the solvent-free syntheses, the yields and purity of the products could be considerably improved. Formation of the oxazine ring $\mathbf{7 1}$ was also noted [30]; similar behavior was previously observed during photochemical or thermal reactions in solution phase [55-57].

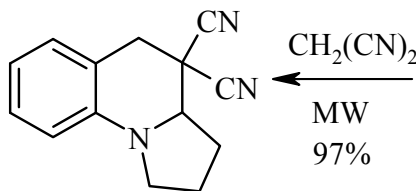

6a<smiles>O=Cc1ccccc1N1CCCC1</smiles>

$4 \mathrm{c}$

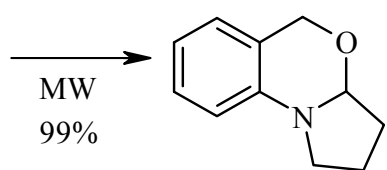

71

It should be noted that all the above-mentioned reactions took place without a catalyst. However, the use of Lewis acids considerably accelerated [26, 58-61] cyclization by the tert-amino effect mechanism and made it possible to extend the applicability of the reaction $[26,61]$. It was also shown that using such acids as trifluoroacetic, $\mathrm{HCl}, \mathrm{HBr}$ or (-)-camphorsulfonic acid allowed to cyclize the vinyl derivatives $\mathbf{7 2}$ containing only one withdrawing group at the double bond [57, 62]. It was noted in the review [3] that for cyclization without a catalyst there should be at least two electron-withdrawing substituents in the vinyl group. 


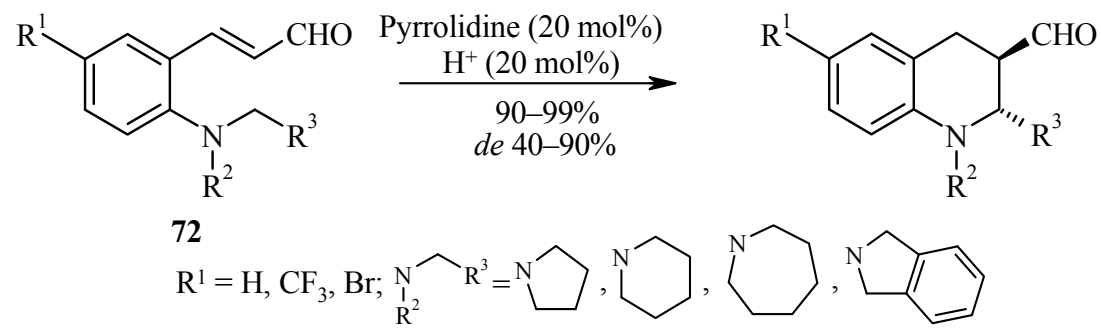

Condensed quinolines $\mathbf{7 3}$ containing only one substituent in the ring were obtained by an alternative method, i.e., by hydrolysis and decarboxylation of the Meldrum's acid derivatives 74 [63].

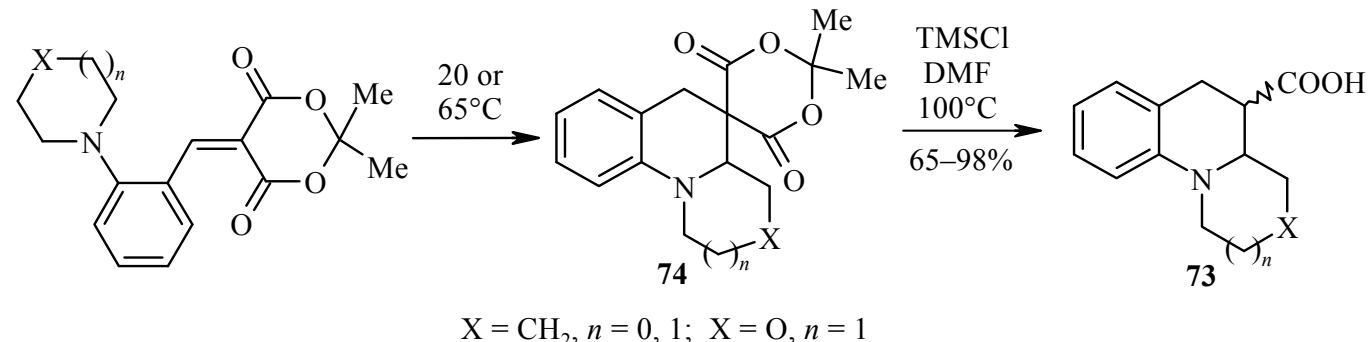

With ruthenium or iridium catalysts [64] it was possible to perform the photocyclization of the chalcone 75 to 5,6-dihydroindolo[2,1-a]tetrahydroisoquinoline $\mathbf{7 6}$.

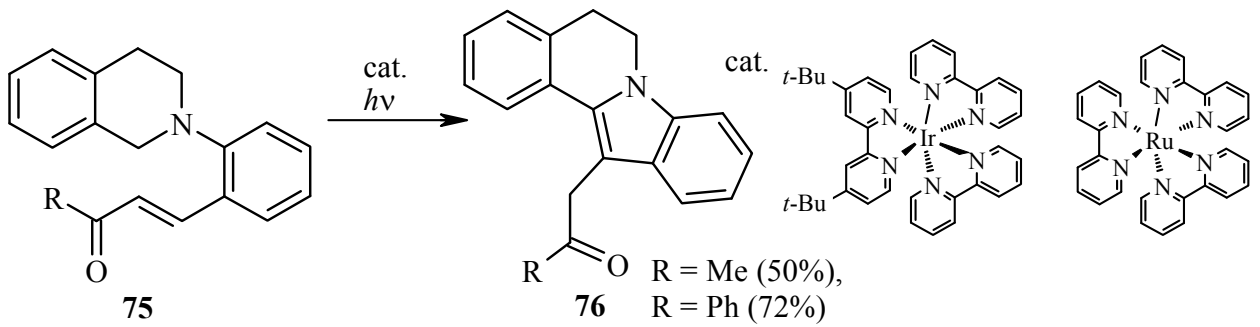

With $\mathrm{TsOH}$ or Lewis acids, such as $\mathrm{Sc}(\mathrm{OTf})_{3}, \mathrm{TiCl}_{4}$, and $\mathrm{SnCl}_{4}$, it was possible $[65,66]$ to achieve a similar cyclization of ortho-benzyloxybenzylidenemalonates $\mathbf{7 7}$, with the formation of benzofurans $\mathbf{7 8}$.

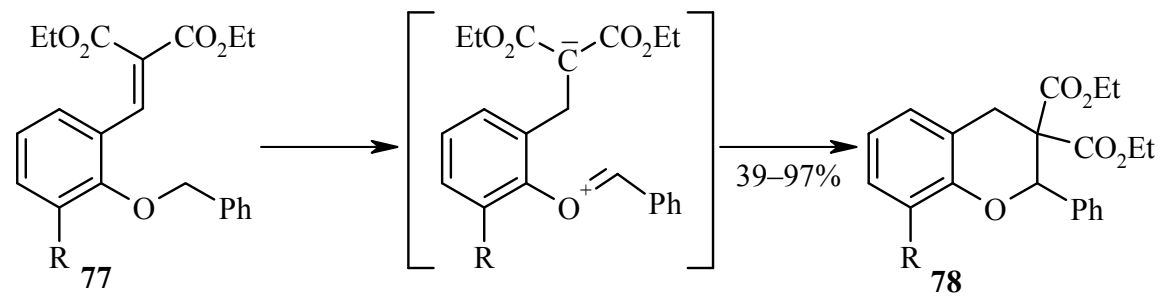

The use of an optically active catalyst in the cyclization of compounds $\mathbf{7 9}$ led to the preparation of one of the enantiomers $\mathbf{8 0}$ (ee 30-97\%) [60, 61]. The use of optically active amines $\mathbf{8 1}$ favored the formation of $(S)$-isomer 82 [67]. 

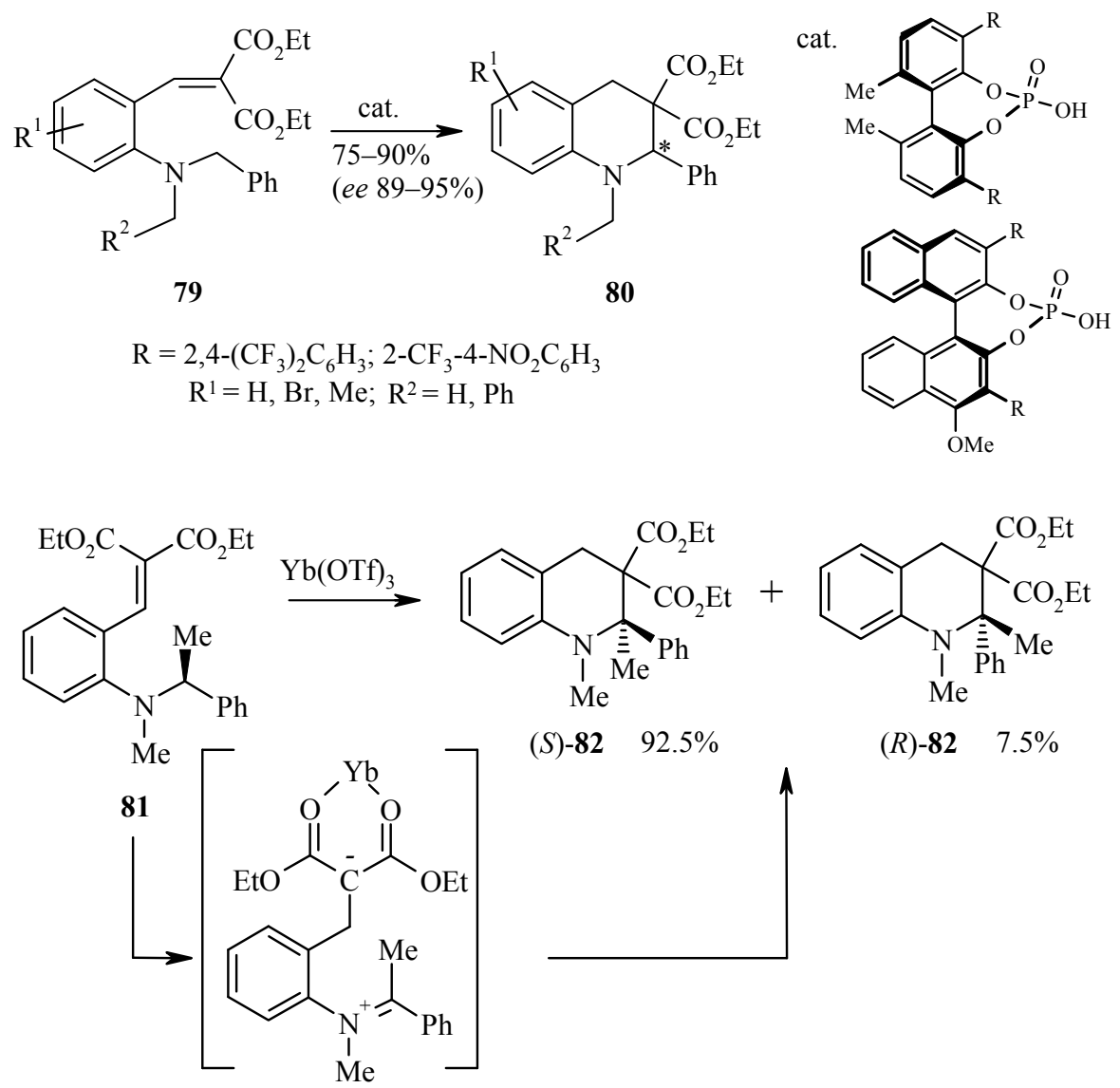

It is important to mention the results described in a remarkable series of papers by Reinhoudt and his colleagues in 1987-1989 [3, 53]. They established that the ring closure could produce regio- and stereoisomers if there was a substituent at the $\alpha$-position relative to the amino group nitrogen. The dinitrile $\mathbf{8 3}$ with $\mathrm{R}^{2}=$ alkyl and $\mathrm{R}^{1}=\mathrm{H}$ underwent regioselective cyclization, including migration of the hydrogen attached to the carbon atom at which there was an alkyl (methyl or ethyl) substituent, and compound $\mathbf{8 4}$ was formed. However, the regioselectivity was significantly lower during the cyclization of $\alpha$-methoxymethyl-substituted derivatives $\left(\mathrm{R}^{1}=\right.$ $\mathrm{H}$ and $\mathrm{R}^{2}=\mathrm{CH}_{2} \mathrm{OMe}$ ), and both possible regioisomers $\mathbf{8 4}$ and $\mathbf{8 5}$ were formed as a result. This was explained by the stabilizing effect of the electron-donating alkyl group with respect to the iminium bond formed in the intermediate [53]. The methoxymethyl group, being less electron-donating and sterically more hindered, reduced the regioselectivity.<smiles>[R]C(=C(C#N)C#N)c1ccccc1N1CCCC1[R]</smiles>

In accordance with the stereochemistry of the reaction, self-reproduction of the chirality was observed during the cyclization of certain chiral substrates, such as the piperidine $\mathbf{8 6}[17,68]$. 


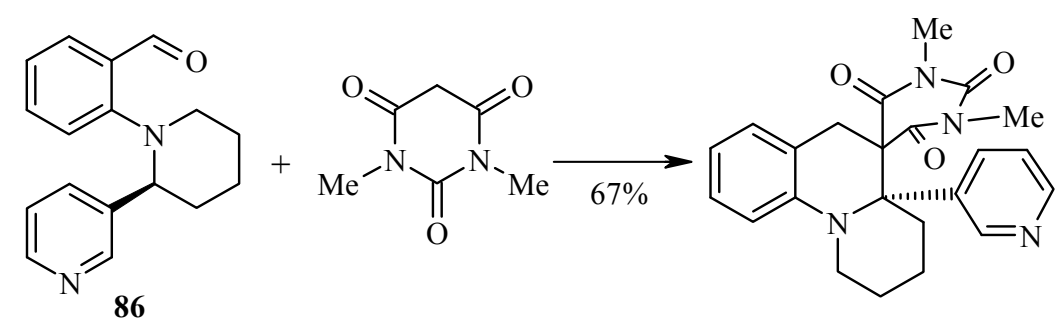

The formation of a $\mathrm{C}-\mathrm{C}$ bond has not been limited to a vinyl substituent at the ortho position relative to the dialkylamino group. Thus, it was demonstrated by Spanish scientists $[69,70]$ that the acetylene fragment of the carbene complex 87 rearranged on heating to the 1,2-dihydroquinoline fragment of compound $\mathbf{8 8}$. It was shown by quantum-chemical calculations that the rate-limiting step was migration of a hydrogen atom, where the activation energy amounted to $29.6 \mathrm{kcal} / \mathrm{mol}$ at $90^{\circ} \mathrm{C}$ [69]. This value was slightly above the experimentally determined activation energy for the cyclization of ortho-vinylanilines 5 at $100^{\circ} \mathrm{C}(24.5 \mathrm{kcal} / \mathrm{mol})$ [37].

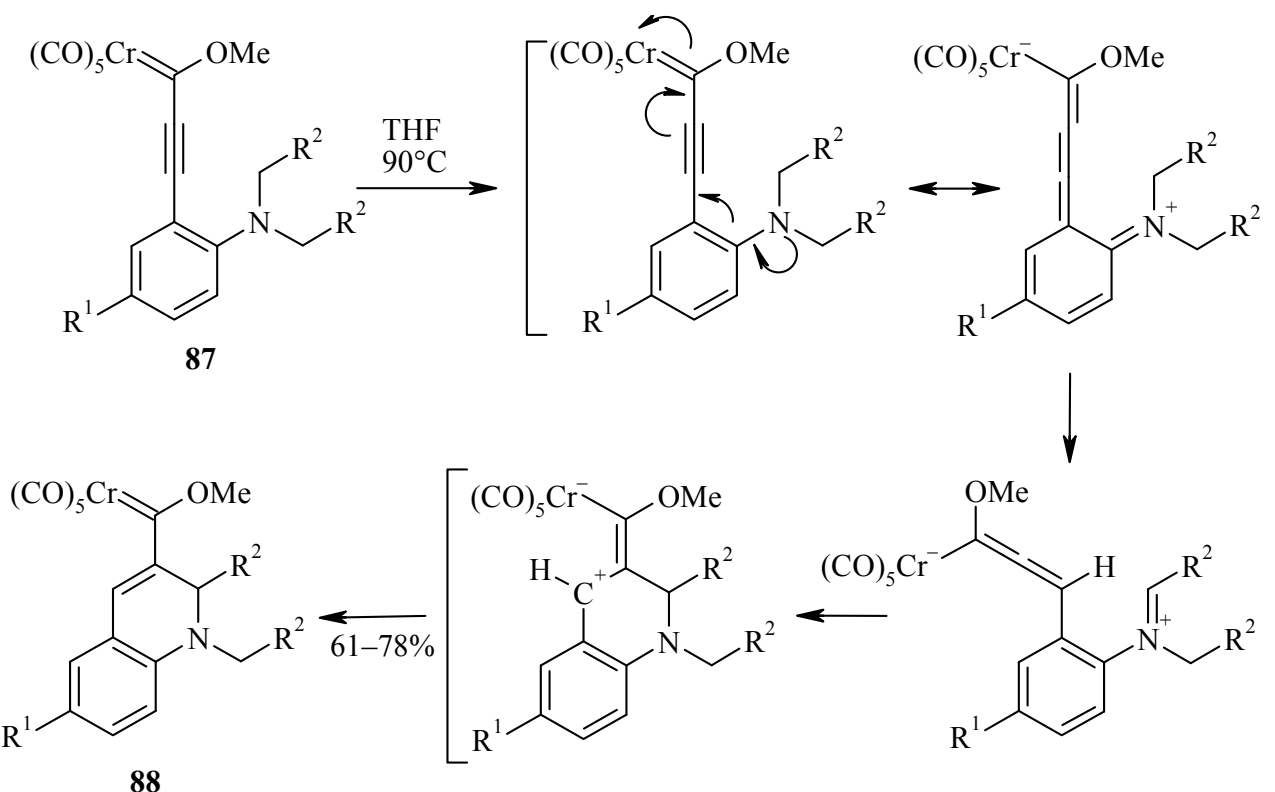<smiles>[2H]C1([2H])CCCCN1c1ccccc1C(C#CC)OC(C)=O</smiles>

90
1) $15 \% \mathrm{PtCl}_{2}, \mathrm{LiCl}$, $\mathrm{CaO}, \mathrm{PhMe}, 110^{\circ} \mathrm{C}$ 2) $\mathrm{K}_{2} \mathrm{CO}_{3}$<smiles>[2H]C1([2H])CCCCN1c1ccccc1C=C(C)c1ccccc1</smiles><smiles>[2H]C1c2ccccc2N2CCCCC2(C)C1C(=O)C(=O)c1ccccc1</smiles> 
Through an experiment with a deuterium-labeled piperidine derivative it was established [71] that the generation of allene $\mathbf{8 9}$ from the propargyl ester $\mathbf{9 0}$ was accompanied by a 1,3-migration of the acyloxy group, a 1,5-hydride shift, and cyclization to tetrahydroquinolines $\mathbf{9 1 .}$

Meth-Cohn [72] noticed that the imines 92 can undergo thermal cyclization of type 3 with the formation of a new $\mathrm{C}-\mathrm{C}$ bond.

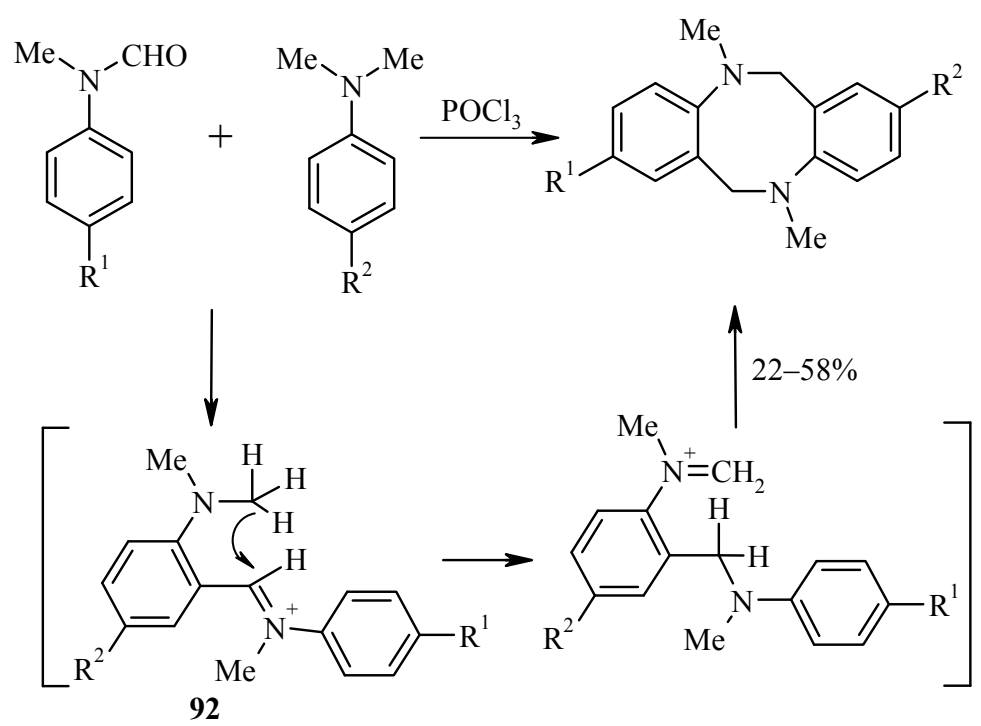

$\mathrm{R}^{1}, \mathrm{R}^{2}=\mathrm{H}, \mathrm{OMe}, \mathrm{Me}, \mathrm{Cl}, \mathrm{Br}, \mathrm{F}$

In the case of a benzyl (compound 93) or methylindole (compound 94) substituent, the cyclization can take place in a (het)aromatic ring with the formation of pyrimidino[4,5-c][2,5]benzodiazocine 95 or indolodiazocine 96 [73]. Such cyclization represents a new variant of the tert-amino effect reaction.
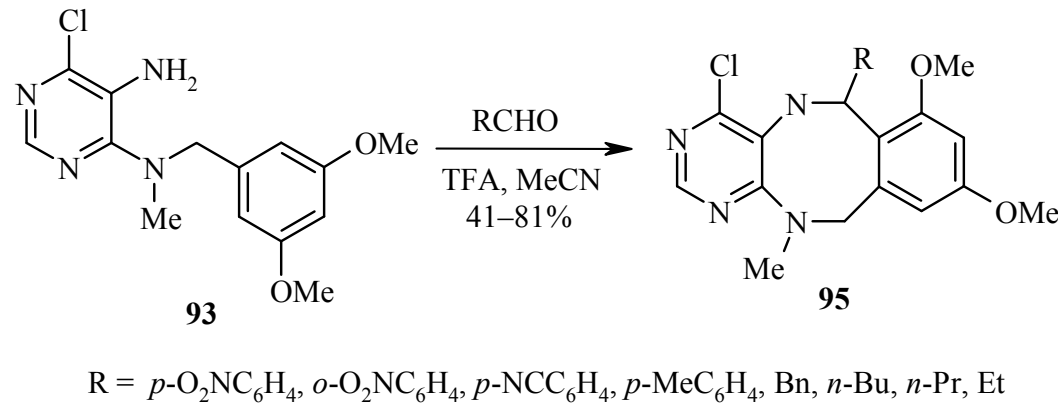<smiles>CN(Cc1cc2ccccc2n1C)c1ncnc(Cl)c1N</smiles>

94<smiles>[R]C1Nc2ncnc(Cl)c2C([R])N(C)Cc2c1c1ccccc1n2C</smiles>

96

$\mathrm{R}=p-\mathrm{O}_{2} \mathrm{NC}_{6} \mathrm{H}_{4}, o-\mathrm{O}_{2} \mathrm{NC}_{6} \mathrm{H}_{4}, p-\mathrm{NCC}_{6} \mathrm{H}_{4}, p-\mathrm{MeC}_{6} \mathrm{H}_{4}, n-\mathrm{Pr}, \mathrm{Et}, \mathrm{HO}_{2} \mathrm{C}$ 
Another example of cyclization involving the $\alpha$-methylene atom of the amino group was demonstrated by Preobrazhenskaya's group [74, 75]. In the presence of strong acids, 2-(dialkylamino)-3-(indol1-yl)maleimides 97 underwent cyclization to 1,4-diazepines 98 annelated to an indole ring [75, 76]. Hydride ion transfer was shown [77] to be the rate-limiting step $(32.9 \mathrm{kcal} / \mathrm{mol})$ [78]. The intramolecular nature of this hydride transfer was confirmed by an experiment with a deuterated alkylamino group [75].<smiles>[R]CN([R])C1=C(n2ccc3ccccc32)C(=O)N([R])C1=O</smiles><smiles>[In][In]</smiles>

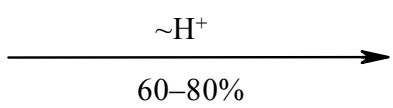

$60-80 \%$<smiles>[R]C1C(=O)N([Z])C(=O)N2CCc3cccc1c32</smiles><smiles>C[InH2]</smiles>

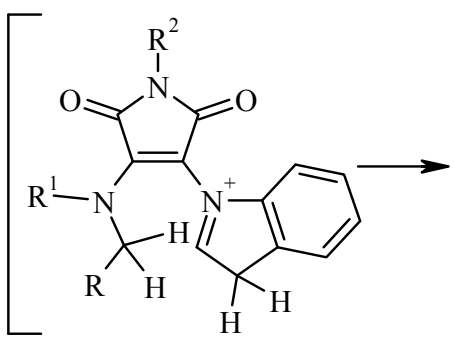<smiles>[R]C[N+]([R])=C1C(=O)N([R2])C(=O)C1N1c2ccccc2C([2H])C1[2H]</smiles><smiles>[R]C1C2C=CC=C3CCCC3(C2)C2=C(C(=O)N([R])C2=O)N1[R]</smiles>

$\mathrm{R}=\mathrm{H}, \mathrm{Me} ; \mathrm{R}^{1}=\mathrm{Me}, \mathrm{Et}, \mathrm{Ph}$

The azocines 101 and 102 were formed by cyclization of arylpyridazines 99 and biaryls 100 [79] containing a dialkylamino group and a vinyl function. In reaction with active methylene components (malonodinitrile, barbituric acids) the biarylcarbaldehyde formed not the vinyl derivatives 100, but rather the cyclization products, phenanthridines $\mathbf{1 0 3}$. The structure of the compounds was proven by NMR spectroscopy and X-ray structural analysis. When heated, these zwitterionic heterocycles $\mathbf{1 0 3}$ rearranged to the dibenzoazocines $\mathbf{1 0 2}$ by the tert-amino effect mechanism [79].<smiles>[R]CN([R])c1cnn(C)c(=O)c1-c1ccccc1C=C([R])[R]</smiles>

99<smiles>[R]C1N([R])c2cnn(C)c(=O)c2-c2ccccc2CC1([R])[R]</smiles>

101

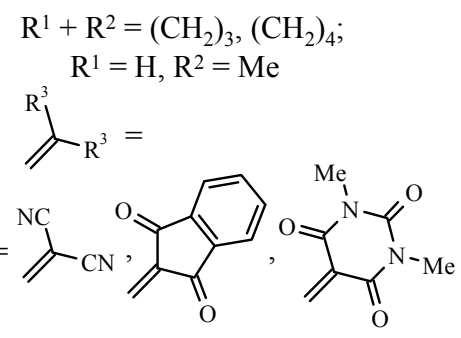<smiles>[R]CN([R])c1ccccc1-c1ccccc1C=C([R])[R]</smiles><smiles>[R]C[N+]1([R])c2ccccc2-c2ccccc2C1C([R])[R]</smiles>

103

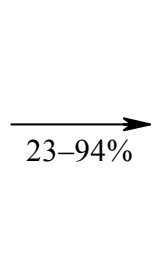<smiles>[R]C1C([R])C([R])([R])Cc2ccccc2-c2ccccc2N1[R]</smiles> 
This type of cyclization was subsequently extended to 1-(o-dialkylaminophenyl)-8-vinylnaphthalenes 104 [80], triaryl derivatives 105, and biarylpyridazines 106 [81]. In these cases, cyclization led to nine- and tenmembered heterocycles 107, 108, and 109.<smiles>[R]C([R])=Cc1cccc2cccc(-c3ccccc3N3CCCC3)c12</smiles>

104<smiles>[R]C1([R])Cc2cccc3cccc(c23)-c2ccccc2N2CCCC21</smiles>

107<smiles>[Y]Cc1ccccc1C=C([R])[R]</smiles><smiles>[R]C1N([R])c2ccccc2-[Y]2ccccc2CC1([R])[R]</smiles>

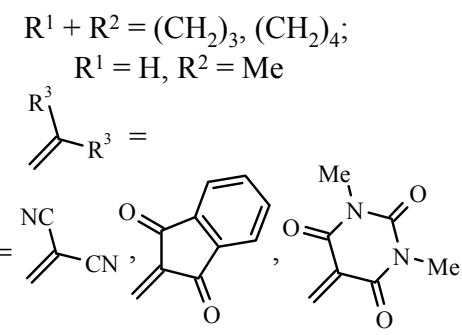

$105,108 \mathrm{X}=$ ; 106,<smiles></smiles>

Seven-membered heterocycles were also formed in the reaction of $o$-dialkylaminobenzaldehydes 4 with indole and dimethylpyrrole [82]. With indole in the presence of acid in alcohol solution, the aminobenzaldehyde 4 usually forms the diindolylmethane 110. Seidel and colleagues [82] showed that in the presence of $p$-toluenesulfonic acid or diphenyl phosphate (DPP) in toluene solution, cyclization occurred at the $\alpha$-carbon atom of dialkylamino group, and a high yield of benzazepinoindole $\mathbf{1 1 1}$ was obtained. The authors proposed that the initially formed diindolylmethane 110 (absent at the end of the reaction) was in equilibrium with the corresponding azofulvenium ion, which underwent cyclization to the azepine 111.

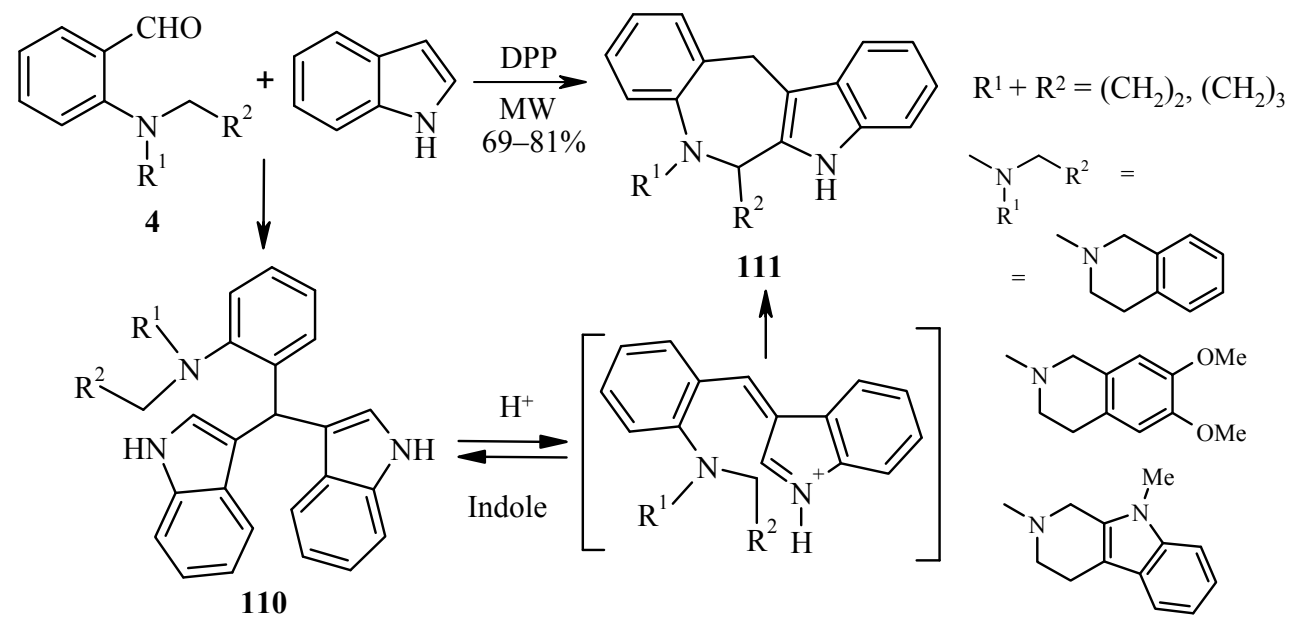


Depending on the catalyst and reaction conditions [83], the ynenone 112 underwent cyclization either to the tetrahydroquinoline $\mathbf{1 1 3}$ or to the azepine $\mathbf{1 1 4}$.

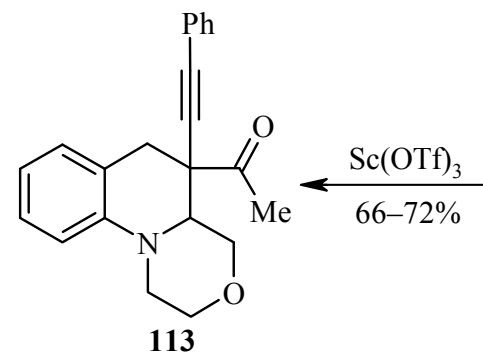<smiles>CC(=O)/C(C#Cc1ccccc1)=C\c1ccccc1N1CCOCC1</smiles><smiles>Cc1oc(-c2ccccc2)c2c1Cc1ccccc1N1CCOCC21</smiles>

Reactions according to the tert-amino effect mechanism require the presence of a conjugation chain with the nitrogen atom of the dialkylamino group. It was shown [84] that 3-[2-(pyrrolidin-1-yl)methylphenyl]acrylonitriles 115 undewent rearrangement to the indanes 116 through a 1,4-hydride shift. At higher temperatures a 1,3-hydrogen shift also occurred with the formation of iminium ion 117, which was transformed into the azepine $\mathbf{1 1 8 .}$

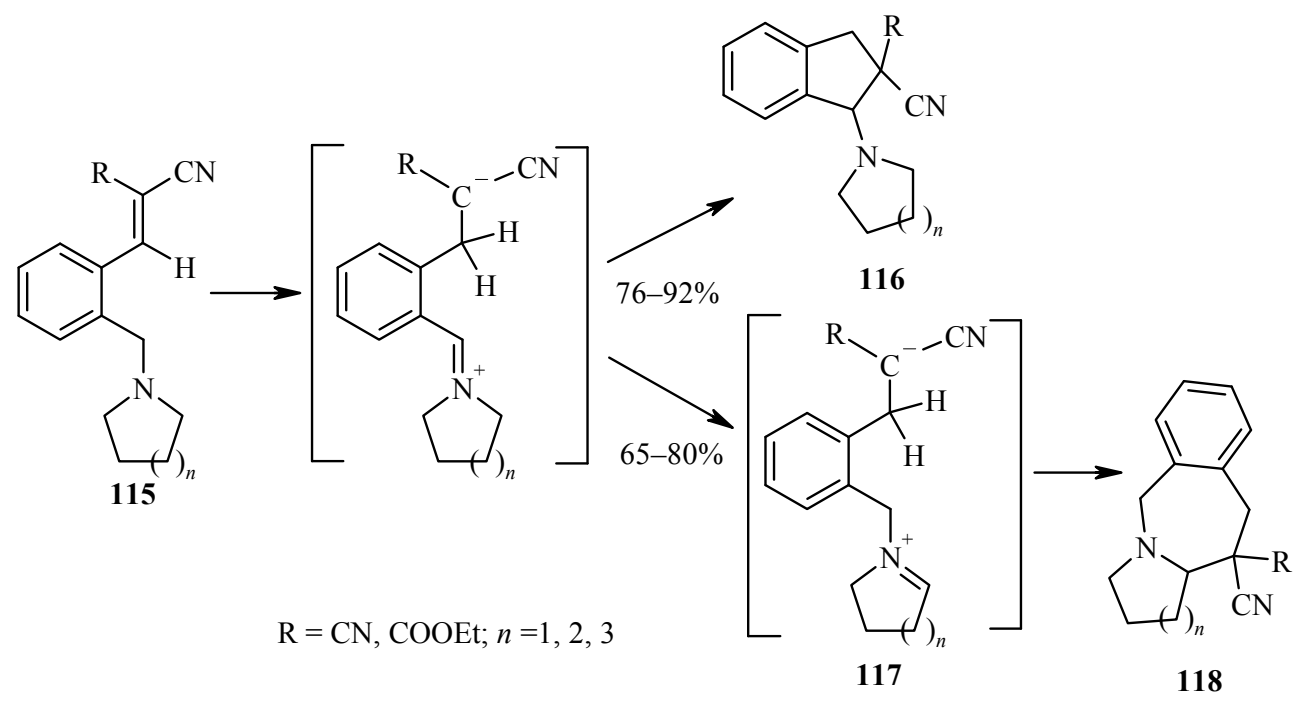

Similar reactions have been reported for the acetylenes 119, which cyclized with the formation of naphthylamines 120 [85].

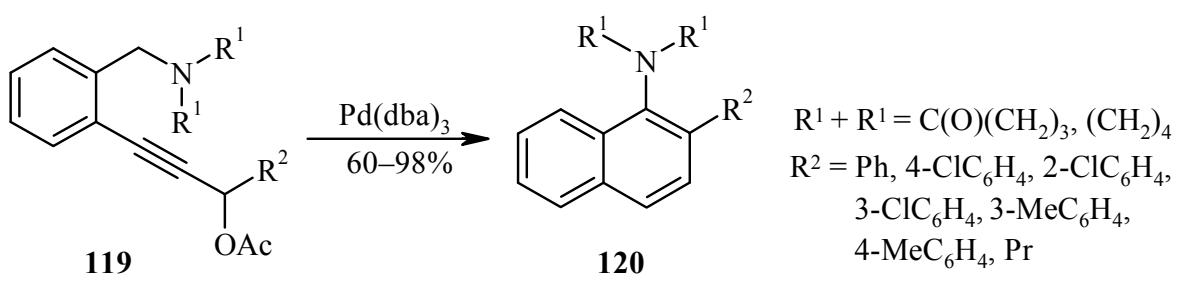

Reinhoudt reactions are also possible in linear structures. Thus, when heated in acetonitrile or DMSO, the dienamines 121a,b underwent a 1,6-hydrogen shift and 1,5-electrocyclization with the formation of pyrrolines 122a,b [86, 87]. 


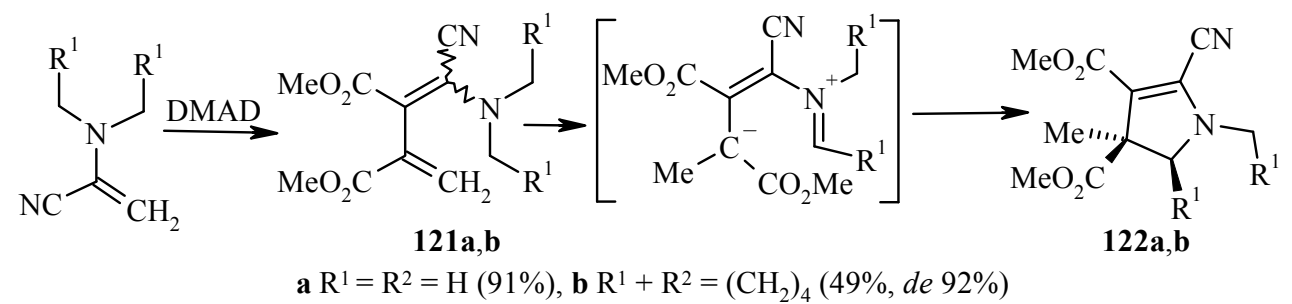

The formed intermediate dipoles $\mathbf{1 2 1}$ were shown to undergo cycloaddition with acrylonitrile or maleimide at the $\alpha$-carbon atom of the amino group. After the elimination of hydrogen cyanide, the vinylpyrroles $\mathbf{1 2 3}$ or $\mathbf{1 2 4}$ were formed [87]. In addition to the cycloaddition product, small amounts of the cyclization products 122 were also isolated.

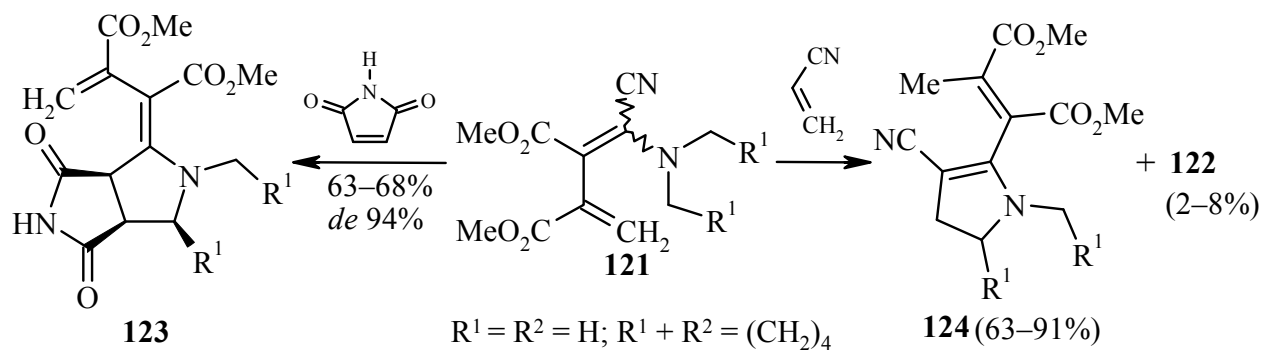

Similar cycloaddition reactions at the $\alpha$-carbon atom of the amino group were demonstrated [88-90] for the azo analogs 125. It was shown by quantum-chemical calculations [89] that the rate-limiting step was proton transfer (with $14.9 \mathrm{kcal} / \mathrm{mol}$ energy barrier).

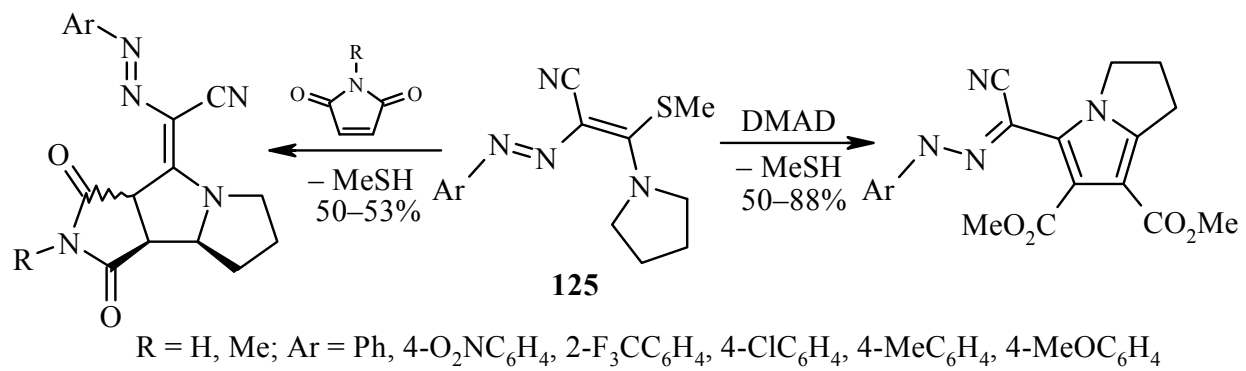

In a series of papers [91-94] it was demonstrated that $N, N$-dialkyl-3-aryltriazenes $\mathbf{1 2 6}$ and $\mathbf{1 2 7}$ cyclized to 1,2,3-triazines 128 when treated with butyllithium. The 1,2,3-triazines without a substituent at the ortho position relative to the triazene group could be transformed into the $\alpha$-aryldialkylamines $\mathbf{1 2 9}$. The key stage was an abstraction of hydrogen from the $\alpha$-carbon atom of the dialkylamino group.

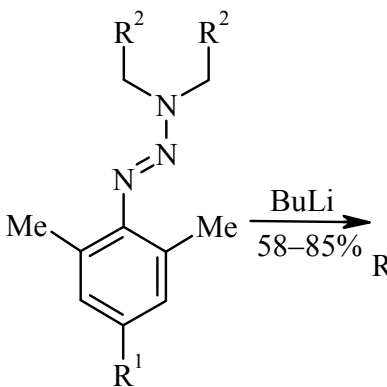

126<smiles>[R]CN1C([R7])C2(C)C=C(I)C=C(C)C2=NN(C(=O)OC(C)(C)C)N1C[Y]</smiles>

128<smiles>[R]CNC([R])c1cccc([R])c1</smiles>

127

$\mathrm{R}^{1}=\mathrm{H}, \mathrm{Me}, \mathrm{OMe}, \mathrm{Cl}, \mathrm{F} ; \mathrm{R}^{2}+\mathrm{R}^{2}=\left(\mathrm{CH}_{2}\right)_{2},\left(\mathrm{CH}_{2}\right)_{3}, \mathrm{R}^{2}=\mathrm{H}$ 
It was recently discovered that $S$-alkenyl sulfoximines $\mathbf{1 3 0}$ underwent cyclization to dihydrothiazetes 131 when refluxed in toluene [95]. In the case of continued refluxing, the thiazines $\mathbf{1 3 2}$ were isolated. In contrast to the thiazete 131, thiazines $\mathbf{1 3 2}$ were isolated as a 1:1 mixture of two diastereomers. Deuterium labeling studies by these authors indicated that the key stage was intramolecular migration of hydride ion.

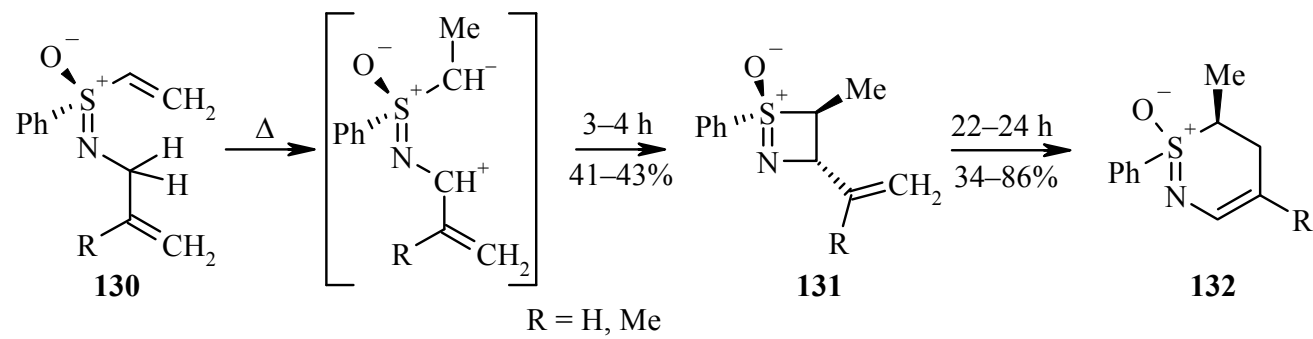

The aminoallenes $\mathbf{1 3 3}$ could also cyclize to azepines $\mathbf{1 3 4}$ when heated [96]. In the reaction of allene $\mathbf{1 3 5}$ with dimethyl acetylenedicarboxylate, the initially formed cyclobutenes $\mathbf{1 3 6}$ rearranged to the condensed rings 137, forming a new $\mathrm{C}-\mathrm{C}$ bond at the $\alpha$-carbon atom of the tertiary amine [97].<smiles>C[N+]1=C(C#Cc2ccccc2)C(C)(C)c2ccccc21</smiles>

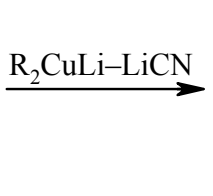<smiles>[R]C(=C=C1N(C)c2ccccc2C1(C)C)c1ccccc1</smiles><smiles>C1=Cc2ccc(nc2)C=C1</smiles><smiles>[R]C1=CC2N(Cc3ccccc31)c1ccccc1C2(C)C</smiles>
$\mathrm{R}=t-\mathrm{Bu}$,<smiles></smiles>

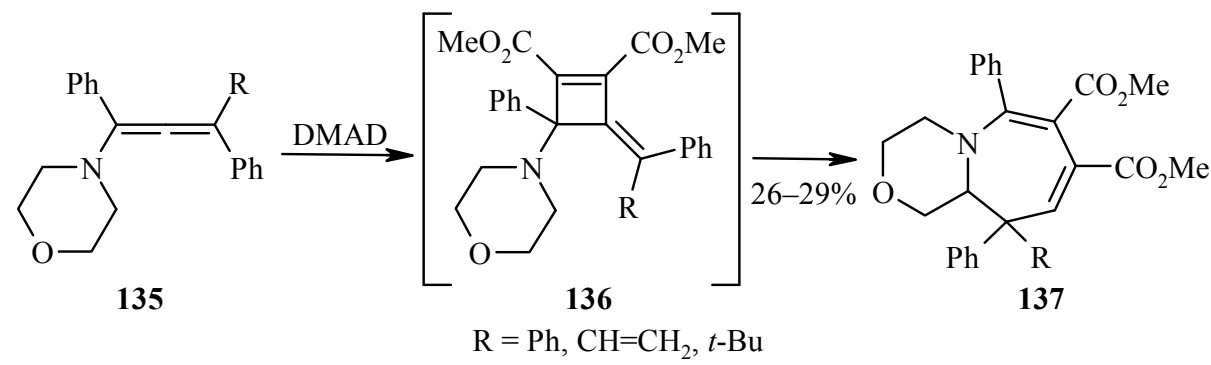

\section{The Meth-Cohn Reaction}

This type of bond formation between an $\alpha$-carbon atom of dialkylamino group and a heteroatom (nitrogen, oxygen), has been reported less frequently the last decade, even though it represents an original method for the synthesis of new heterocyclic systems. Thus, it was demonstrated [98] that 6-(dialkylamino)5-nitrosopyrimidines 138 underwent thermal cyclization to condensed purines $\mathbf{1 3 9}$. 


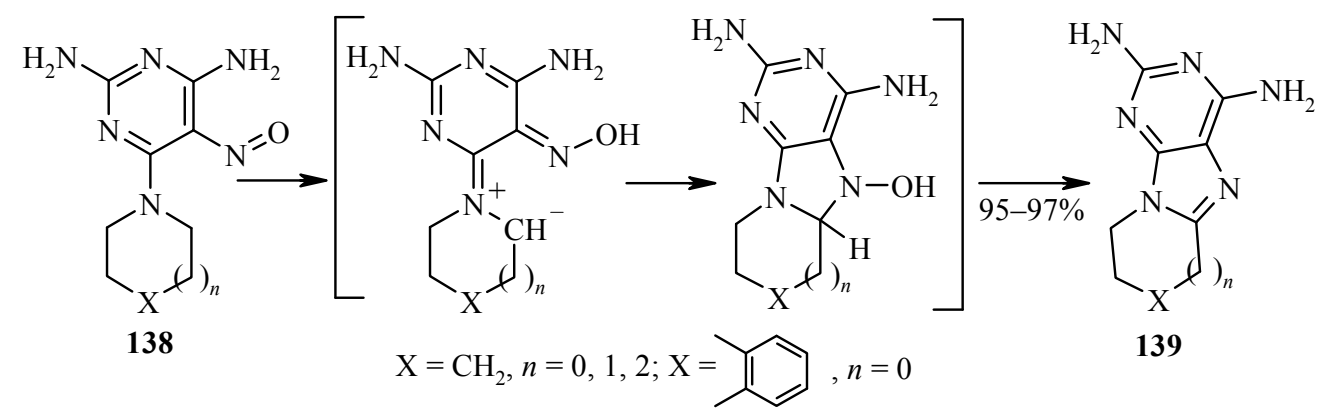

As mentioned earlier [11, 31], ortho-dialkylaminobenzaldehydes 4 cyclized to the benzoxazines $\mathbf{7 1}$ upon microwave irradiation. Trifluoroacetophenones likewise cyclized to benzoxazines upon heating [55-57]. This reaction was recently used to modify the $\alpha$-position of a dialkylamino group [99]. Thus, the benzoxazines 71 formed by heating of benzaldehydes 4 in the presence of scandium triflate, were treated upon cooling with a Grignard reagent or lithium alkynyl trifluoroborate. As a result of oxazine ring opening, the functionalized hydroxymethylanilines 140 were obtained.

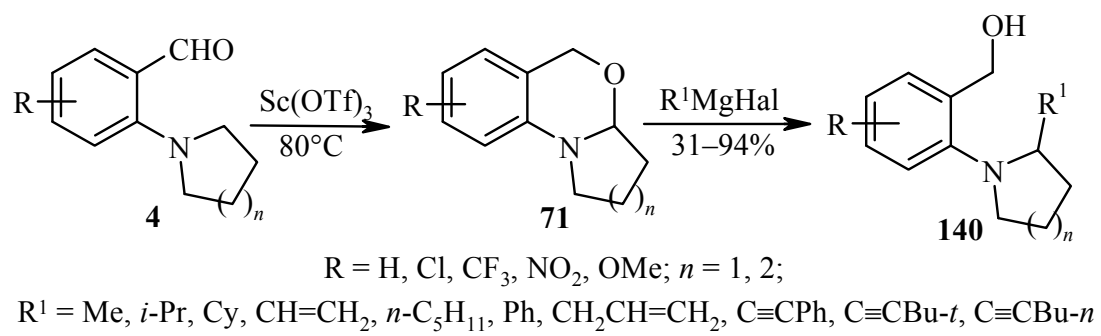

Schiff bases also undergo the Meth-Cohn reaction. Thus, in reaction with primary amines in the presence of Brønsted acids, 2-dialkylaminobenzaldehydes 4 formed the condensed benzopyrimidines 141 [100].<smiles>[R]N1Cc2ccccc2N2CCCC12</smiles>

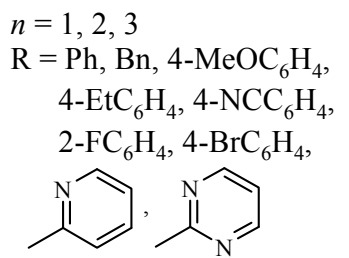

2-Aminobenzaldehydes 142 reacted similarly with dialkylamines and formed the fused quinazolines 143 [101].

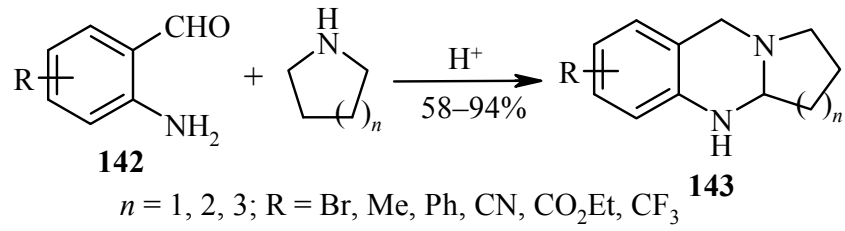

It was also shown that ortho-aminobenzo ketones 144 reacted with anilines in the presence of chiral Brønsted acids and formed compounds 145 with good yields and high enantioselectivity [102]. 


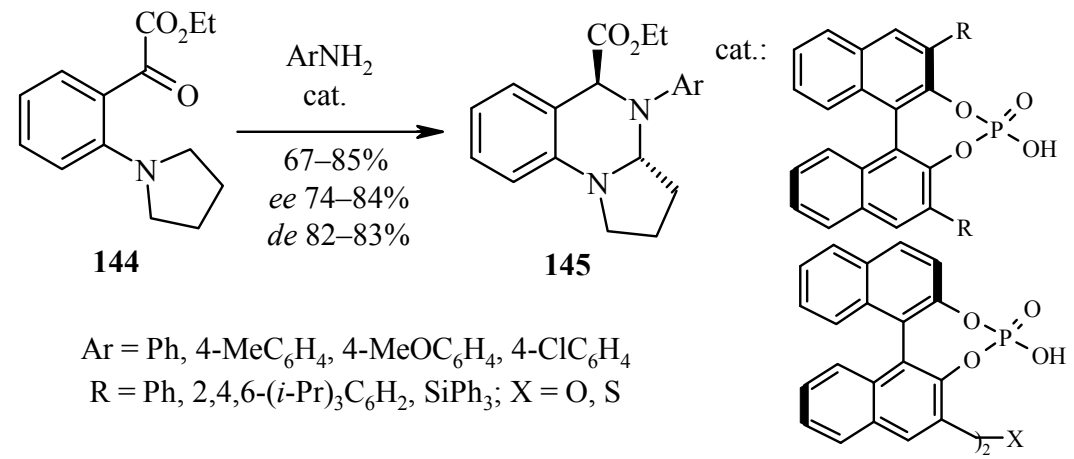

Unlike the imines, the hydrazone 146 cyclized to the indoline 147 with loss of the azo fragment and formation of a new $\mathrm{C}-\mathrm{C}$ bond [103]. The authors suggested two possible mechanisms, i.e., the tert-amino effect (path A) and through the formation of the carbene $\mathbf{1 4 8}$ (path B).

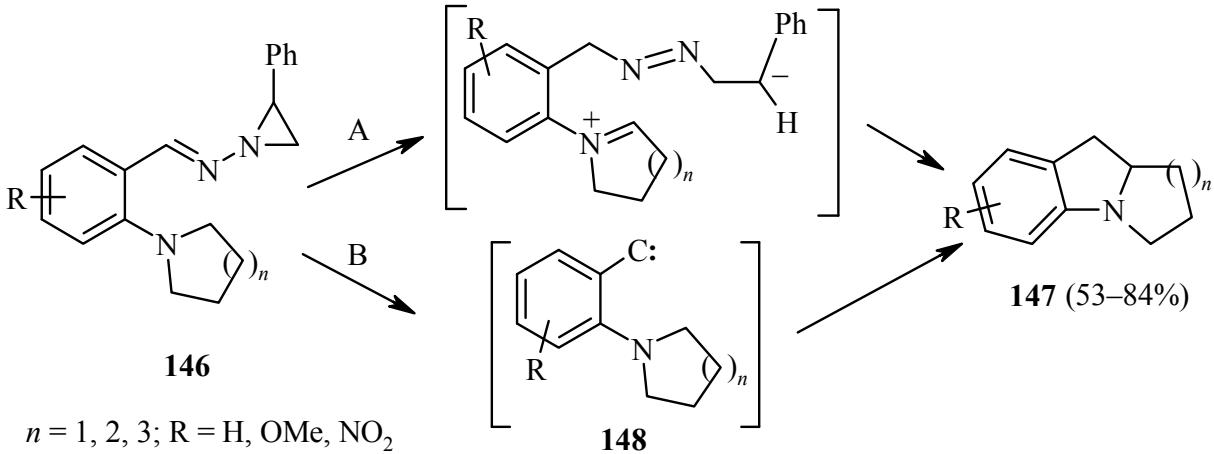

The reaction of $N, N$-dialkyl-ortho-diaminobenzene $149[104,105]$ with aldehydes and ketones in the presence of Lewis acid led to a 1,6-hydride shift and cyclization at the $\alpha$-carbon atom of the dialkylamino group with the formation of a $\mathrm{C}-\mathrm{N}$ bond and formation of the benzimidazole $\mathbf{1 5 0}$.<smiles>[R]CN(C[R])c1ccc([R])cc1N</smiles>

$\mathrm{R}^{1}+\mathrm{R}^{1}=\left(\mathrm{CH}_{2}\right)_{2},\left(\mathrm{CH}_{2}\right)_{4}, \mathrm{R}^{1}=\mathrm{Me}, \mathrm{Et} ; \mathrm{R}^{2}=\mathrm{SO}_{2} \mathrm{Ph}, \mathrm{SOC}_{6} \mathrm{H}_{4} \mathrm{Me}-4, \mathrm{Cl}, \mathrm{CF}_{3} ;$ $\mathrm{R}^{3}=\mathrm{H}, \mathrm{Me} ; \mathrm{R}^{4}=\mathrm{Ph}, 4-\mathrm{MeOC}_{6} \mathrm{H}_{4}, 4-\mathrm{ClC}_{6} \mathrm{H}_{4}, 5$-methylthiophen-2-yl

1,2-Diaza-1,3-butadienes 151, containing allyl(propargyl)sulfanyl and cyclic dialkylamino groups, produced 1,2,4-triazines 152 by thermal cyclization [106, 107]. Furthermore, in the case of an allylsulfanyl group it was shown that propene was eliminated in this reaction [106].

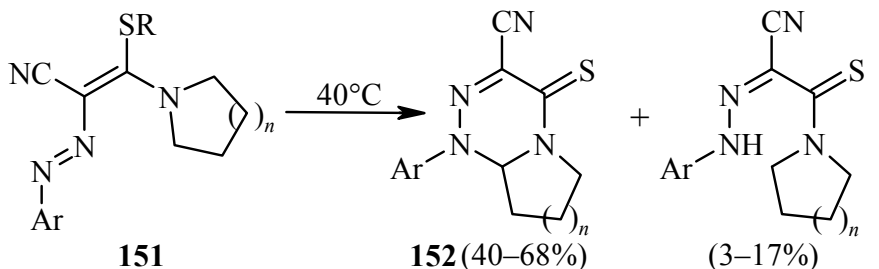

$$
n=1,2 ; \mathrm{R}=\mathrm{CH}_{2} \mathrm{CH}=\mathrm{CH}_{2}, \mathrm{CH}_{2} \mathrm{C} \equiv \mathrm{CH} ; \mathrm{Ar}=\mathrm{Ph}, 4-\mathrm{MeC}_{6} \mathrm{H}_{4}, 4-\mathrm{MeOC}_{6} \mathrm{H}_{4}, 4-\mathrm{O}_{2} \mathrm{NC}_{6} \mathrm{H}_{4}
$$


It should be noted that not all reactions involving hydrogen transfer from the $\alpha$-carbon atom of a dialkylamino group result in cyclization. Examples of intramolecular oxidation-reduction (intramolecular redox processes) have been described. Thus, a reaction of the dihydropyrrole 153 with aldehydes and ketones

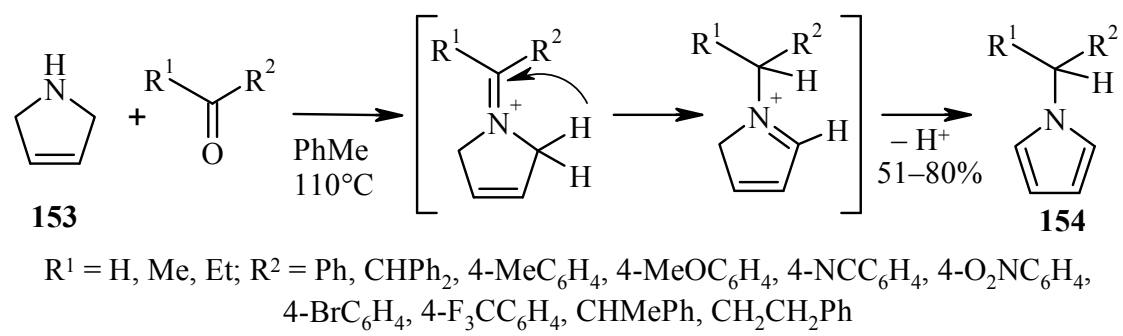

in the presence of acids led to dehydrogenation of the heterocycle and hydrogenation of the formed Schiff base resulting in the 1-substituted pyrrole 154 [108]. The reaction with indoline 155 similarly led to the indoles 156 $[109,110]$. Tunge and colleagues [108] suggested that a 1,3-migration of hydrogen was the key step of this process.

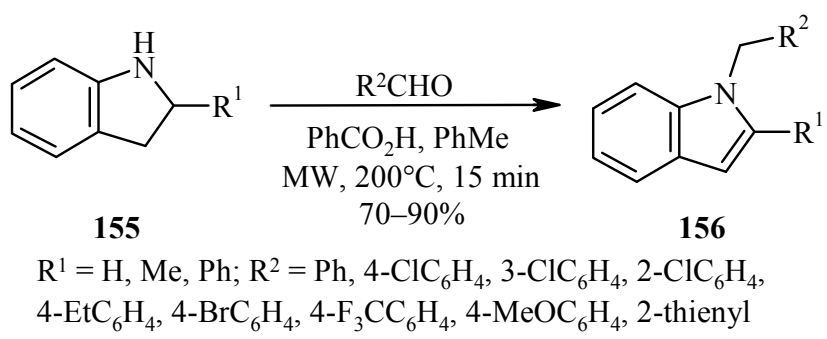

On the basis of quantum-chemical calculations Chinese scientists [110] proposed that the reaction took place by an intermolecular proton transfer mechanism with an activation energy of $25.6 \mathrm{kcal} / \mathrm{mol}$ in a solvent, whereas a 1,3-migration of the proton would have a barrier of $44.6 \mathrm{kcal} / \mathrm{mol}$.

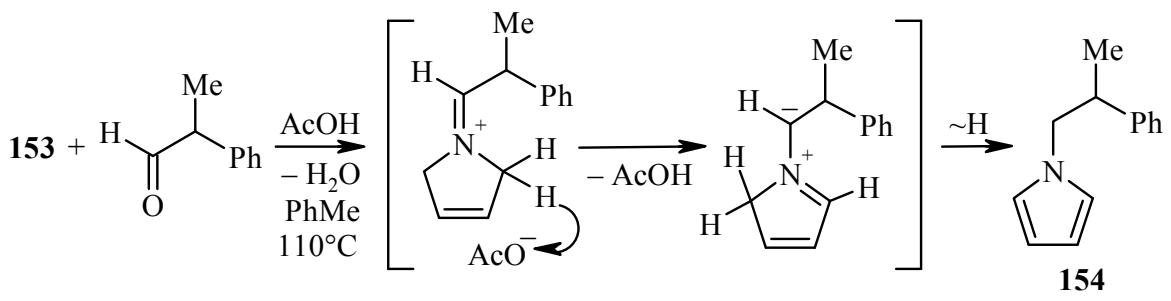

We showed [111] that a reductive elimination of dialkylamino group with the formation of nitroimidazole 158 took place when 4-(N,N-dialkylamino)-5-nitroimidazoles 157 were refluxed in butanol. A mechanism with hydride transfer to the nitro group as the key step was proposed $[1,3]$.

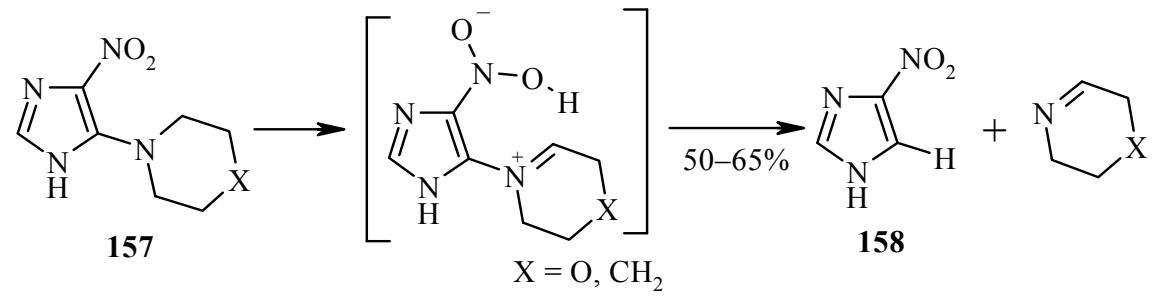

Later [112] Rees showed that pyrazolidine-3,5-dione $\mathbf{1 6 0}$ was formed when the hydrazide $\mathbf{1 5 9}$ was heated in pyridine. 


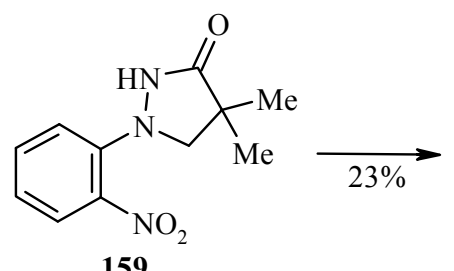<smiles>CC1(C)C(=O)NN(c2ccccc2)C1=O</smiles>

The authors proposed the following mechanism of denitration: The first stage involved an intramolecular hydride shift to the nitro group oxygen, and the iminium ion $\mathbf{1 6 1}$ then underwent rearrangement to the nitroso compound 162, which was in equilibrium with the hydroxylamine 163. Elimination of an $\mathrm{H}-\mathrm{N}=\mathrm{O}$ molecule would conclude this process.

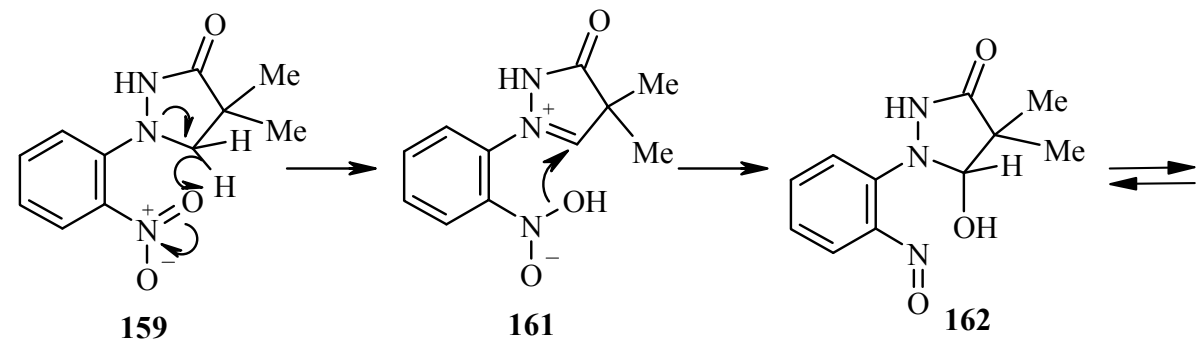

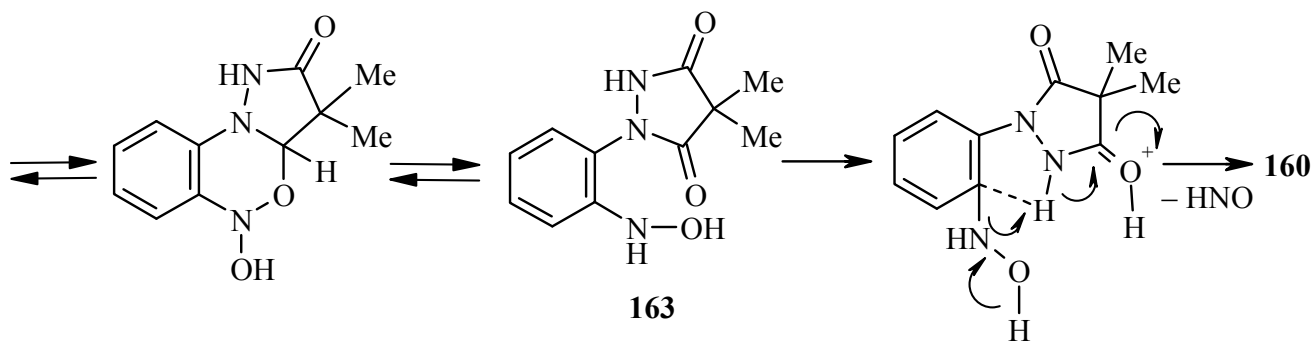

Thus, the concept of the tert-amino effect includes not only cyclization but also elimination, hydrogenation-dehydrogenation, alkylation, and other reactions where the key step is hydrogen migration from the $\alpha$-carbon atom of a dialkylamino group.

In conclusion we would like to point out that the Meth-Cohn and Reinhoudt reactions have previously been represented by individual uncoordinated examples, whereas in the last two decades they have evolved into a new direction of heterocyclic synthesis. The data analysed in the review allow us to expect rapid development of reactions occurring by the tert-amino effect mechanism in the immediate future.

\section{REFERENCES}

1. O. Meth-Cohn and H. Suschitzky, Adv. Heterocycl. Chem., 14, 211 (1972).

2. J. Pinnow, Ber. Dtsch. Chem. Ges., 28, 3039 (1895).

3. W. Verboom and D. N. Reinhoudt, Recl. Trav. Chim. Pays-Bas, 109, 311 (1990).

4. O. Meth-Cohn, Adv. Heterocycl. Chem., 65, 1 (1996).

5. J. M. Quintela, Recent Res. Dev. Org. Chem., 7, 259 (2003).

6. E. V. D'yachenko, T. V. Glukhareva, L. V. Dyudya, O. V. Eltsov, and Yu. Yu. Morzherin, Molecules, 10, 1101 (2005).

7. P. Mátyus, O. Éliás, P. Tapolcsányi, Á. Polonka-Bálint, and B. Halász-Dajka, Synthesis, 2625 (2006).

8. W. Verboom, D. N. Reinhoudt, R. Visser, and S. Harkema, J. Org. Chem., 49, 269 (1984). 
9. L. C. Groenen, W. Verboom, W. H. N. Nijhuis, D. N. Reinhoudt, G. J. Van Hummel, and D. Feil, Tetrahedron, 44, 4637 (1988).

10. A. Schwartz, G. Beke, Z. Kovári, Z. Böcskey, Ö. Farkas, and P. Mátyus, J. Mol. Struct.: THEOCHEM, 528, 49 (2000).

11. N. Kaval, W. Dehaen, P. Mátyus, and E. Van der Eycken, Green Chem., 6, 125 (2004).

12. V. V. Lobodin, V. V. Ovcharenko, K. Pihlaja, Yu. Yu. Morzherin, and A. T. Lebedev, Rapid Commun. Mass Spectrom., 18, 724 (2004).

13. W. H. N. Nijhuis, W. Verboom, A. A. El-Fadl, G. J. Van Hummel, and D. N. Reinhoudt, J. Org. Chem., 54, 209 (1989).

14. E. Kelderman, H. G. Noorlander-Bunt, W. Verboom, and D. N. Reinhoudt, Recl. Trav. Chim. Pays-Bas, 110, 115 (1991).

15. W. Verboom, Yu. Morzherin, E. Kelderman, J. F. J. Engbersen, D. N. Reinhoudt, G. J. van Hummel, and S. Harkema, Recl. Trav. Chim. Pays-Bas, 112 , 549 (1993).

16. C. Rabong, C. Hametner, K. Mereiter, V. G. Kartsev, and U. Jordis, Heterocycles, 75, 799 (2008).

17. C. Rabong, C. Valla, V. G. Kartsev, and U. Jordis, Mendeleev Commun., 17, 318 (2007).

18. V. Ojea, C. Peinador, J. Vilar, and J. M. Quintela, Synthesis, 152 (1993).

19. V. Ojea, I. Muinelo, M. C. Figueroa, M. Ruiz, and J. M. Quintela, Synlett, 622 (1995).

20. H. Wamhoff and V. Kramer-Hoß, Liebigs Ann./Recl., 1997, 1619 (1997).

21. P. J. Bhuyan, K. C. Lekhok, and J. S. Sandhu, J. Chem. Res., Synop., 502 (1998).

22. V. Ojea, I. Muinelo, and J. M. Quintela, Tetrahedron, 54, 927 (1998).

23. P. Mátyus, K. Fuji, and K. Tanaka, Heterocycles, 37, 171 (1994).

24. B. Dajka-Halász, Á. A. Földi, K. Ludányi, and P. Mátyus, ARKIVOC, iii, 102 (2008).

25. T. V. Glukhareva, E. P. Klimova, A. Yu. Platonova, and Yu. Yu. Morzherin, Khim. Geterotsikl. Soedin., 942 (2008). [Chem. Heterocycl. Compd., 44, 759 (2008)].

26. D. Prajapati and K. J. Borah, Beilstein J. Org. Chem., 3, 43 (2007).

27. A. V. Tverdokhlebov, A. P. Gorulya, A. A. Tolmachev, A. N. Kostyuk, A. N. Chernega, and E. B. Rusanov, Synthesis, 2161 (2005).

28. S. V. Ryabukhin, A. S. Plaskon, D. M. Volochnyuk, A. N. Shivanyuk, and A. A. Tolmachev, Synthesis, 2872 (2007).

29. L. Károlyházy, G. Regdon, O. Éliás, G. Beke, T. Tábi, K. Hódi, I. Erős, and P. Mátyus, J. Mol. Struct.: THEOCHEM, 666-667, 667 (2003).

30. P. Mátyus, B. U. W. Maes, Z. Riedl, G. Hajós, G. L. F. Lemière, P. Tapolcsányi, K. Monsieurs, O. Éliás, R. A. Dommisse, and G. Krajsovszky, Synlett, 1123 (2004).

31. N. Kaval, B. Halasz-Dajka, G. Vo-Thanh, W. Dehaen, J. Van der Eycken, P. Mátyus, A. Loupy, and E. Van der Eycken, Tetrahedron, 61, 9052 (2005).

32. T. V. Glukhareva, E. V. Dyachenko, and Yu. Yu. Morzherin, Khim. Geterotsikl. Soedin., 1610 (2002). [Chem. Heterocycl. Compd., 38, 1426 (2002).]

33. E. V. Dyachenko, T. V. Glukhareva, and Yu. Yu. Morzherin, Khim. Geterotsikl. Soedin., 1737 (2003). [Chem. Heterocycl. Compd., 39, 1532 (2003).]

34. E. V. Dyachenko, T. V. Glukhareva, E. F. Nikolaenko, A. V. Tkachev, and Yu. Yu. Morzherin, Izv. Acad. Nauk, Ser. Khim., 53, 1191 (2004). [Russ. Chem. Bull., 53, 1240 (2004)].

35. K. A. Krasnov and V. G. Kartsev, Zh. Org. Khim., 41, 920 (2005). [Russ. J. Org. Chem., 41, 901 (2005)].

36. K. A. Krasnov, V. G. Kartsev, and V. N. Khrustalev, Tetrahedron, 66, 6054 (2010).

37. K. A. Krasnov, V. G. Kartsev, and V. N. Khrustalev, Mendeleev Commun., 16, 52 (2006).

38. I. V. Paramonov, N. A. Belyaev, T. V. Glukhareva, A. S. Volkov, E. V. Deeva, and Yu. Yu. Morzherin, Khim. Geterotsikl. Soedin., 141 (2006). [Chem. Heterocycl. Compd., 42, 127 (2006)]. 
39. E. V. Deeva, T. V. Glukhareva, N. A. Zybina, and Yu. Yu. Morzherin, Izv. Akad. Nauk, Ser. Khim., 54, 1492 (2005). [Russ. Chem. Bull., 54, 1537 (2005)].

40. E. V. Deeva, T. V. Glukhareva, A. V. Tkachev, and Yu. Yu. Morzherin, Mendeleev Commun., 16, 82 (2006).

41. T. V. Glukhareva, E. V. Deeva, A. Yu. Platonova, I. V. Geide, M. I. Kodess, and Yu. Yu. Morzherin, Zh. Org. Khim., 45, 743 (2009). [Russ. J. Org. Chem., 45, 743 (2009)].

42. K. A. Krasnov, V. G. Kartsev, and V. N. Khrustalev, Khimiya Prirod. Soedinenii, 44, 38 (2008). [Chem. Nat. Compd., 44, 48 (2008)].

43. M. R. Barbachyn, P. J. Dobrowolski, A. R. Hurd, D. J. McNamara, J. R. Palmer, A. G. Romero, J. C. Ruble, D. A. Sherry, L. M. Thomasco, and P. L. Toogood, WO Pat. Appl. 2004031195.

44. A. A. Miller, G. L. Bundy, J. E. Mott, J. E. Skepner, T. P. Boyle, D. W. Harris, A. E. Hromockyj, K. R. Marotti, G. E. Zurenko, J. B. Munzner, M. T. Sweeney, G. F. Bammert, J. C. Hamel, C. W. Ford, W.-Z. Zhong, D. R. Graber, G. E. Martin, F. Han, L. A. Dolak, E. P. Seest, J. C. Ruble, G. M. Kamilar, J. R. Palmer, L. S. Banitt, A. R. Hurd, and M. R. Barbachyn, Antimicrob. Agents Chemother., 52, 2806 (2008).

45. J. C. Ruble, A. R. Hurd, T. A. Johnson, D. A. Sherry, M. R. Barbachyn, P. L. Toogood, G. L. Bundy, D. R. Graber, and G. M. Kamilar, J. Am. Chem. Soc., 131, 3991 (2009).

46. J. C. Ruble, A. R. Hurd, and T. A. Johnson, Chemtracts, 23, 21 (2010).

47. T. V. Glukhareva, P. E. Kropotina, M. F. Kosterina, Yu. I. Nein, E. V. Deeva, and Yu. Yu. Morzherin, Khim. Geterotsikl. Soedin., 90 (2007). [Chem. Heterocycl. Compd., 43, 76 (2007)].

48. A. V. Tverdokhlebov, A. P. Gorulya, A. A. Tolmachev, A. N. Kostyuk, A. N. Chernega, and E. B. Rusanov, Tetrahedron, 62, 9146 (2006).

49. I. Devi, B. Baruah, and P. J. Bhuyan, Synlett, 2593 (2006).

50. I. C. Ivanov, T. N. Glasnov, and F. Belaj, J. Heterocycl. Chem., 45, 177 (2008).

51. M. A. Povalyakhina, A. F. Pozharskii, O. V. Dyablo, V. A. Ozeryanskii, and O. V. Ryabtsova, Mendeleev Commun., 20, 36 (2010).

52. A. F. Pozharskii, M. A. Povalyakhina, A. V. Degtyarev, O. V. Ryabtsova, V. A. Ozeryanskii, O. V. Dyablo, A. V. Tkachuk, O. N. Kazheva, A. N. Chekhlov, and O. A. Dyachenko, Org. Biomol. Chem., 9, 1887 (2011).

53. W. H. N. Nijhuis, W. Verboom, A. A. El-Fadl, S. Harkema, and D. N. Reinhoudt, J. Org. Chem., 54, 199 (1989).

54. S. Majumder and P. J. Bhuyan, Synlett, 173 (2011).

55. E. P. Fokin and V. V. Russkikh, Zh. Org. Khim., 2, 907 (1966).

56. W. Verboom, B. G. van Dijk, and D. N. Reinhoudt, Tetrahedron Lett., 24, 3923 (1983).

57. W. H. N. Nijhuis, W. Verboom, D. N. Reinhoudt, and S. Harkema, Recl. Trav. Chim. Pays-Bas, 108, 147 (1989).

58. S. Murarka, I. Deb, C. Zhang, and D. Seidel, J. Am. Chem. Soc., 131, 13226 (2009).

49. S. Murarka, C. Zhang, M. D. Konieczynska, and D. Seidel, Org. Lett., 11, 129 (2009).

60. K. Mori, K. Ehara, K. Kurihara, and T. Akiyama, J. Am. Chem. Soc., 133, 6166 (2011).

61. W. Cao, X. Liu, W. Wang, L. Lin, and X. Feng, Org. Lett., 13, 600 (2011).

62. Y. K. Kang, S. M. Kim, and D. Y. Kim, J. Am. Chem. Soc., 132, 11847 (2010).

63. S. V. Ryabukhin, A. S. Plaskon, D. M. Volochnyuk, S. E. Pipko, and A. A. Tolmachev, Synth. Commun., 38, 3032 (2008).

64. P. Kohls, D. Jadhav, G. Pandey, and O. Reiser, Org. Lett., 14, 672 (2012).

65. K. M. McQuaid, J. Z. Long, and D. Sames, Org. Lett., 11, 2972 (2009).

66. K. Mori, T. Kawasaki, S. Sueoka, and T. Akiyama, Org. Lett., 12, 1732 (2010).

67. L. Chen, L. Zhang, J. Lv, J.-P. Cheng, and S. Luo, Chem.-Eur. J., 18, 8891 (2012). 
68. K. A. Krasnov and V. G. Kartsev, Khimiya Prirod. Soedinenii, 46, 779 (2011). [Chem. Nat. Compd., 46, 915 (2011)].

69. J. Barluenga, M. Fañanás-Mastral, F. Aznar, and C. Valdés, Angew. Chem., Int. Ed., 47, 6594 (2008).

70. J. Barluenga, M. Fañanás-Mastral, A. Fernández, and F. Aznar, Eur. J. Org. Chem., 1961 (2011).

71. X.-F. Xia, X.-R. Song, N. Wang, H.-L. Wei, X.-Y. Liu, and Y.-M. Liang, RSC Adv., 2, 560 (2012).

72. Y. Cheng, P. Jiao, D. J. Williams, and O. Meth-Cohn, J. Chem. Soc., Perkin Trans. 1, 44 (2001).

73. X. Che, L. Zheng, Q. Dang, and X. Bai, J. Org. Chem., 73, 1147 (2008).

74. S. A. Lakatosh, Y. N. Luzikov, and M. N. Preobrazhenskaya, Org. Biomol. Chem., 1, 826 (2003).

75. S. A. Lakatosh, Y. N. Luzikov, and M. N. Preobrazhenskaya, Tetrahedron, 61, 2017 (2005).

76. S. A. Lakatosh, Y. N. Luzikov, and M. N. Preobrazhenskaya, Tetrahedron, 61, 8241 (2005).

77. E. E. Bykov, S. A. Lakatosh, and M. N. Preobrazhenskaya, Izv. Akad. Nauk, Ser. Khim., 55, 754 (2006). [Russ. Chem. Bull., 55, 781 (2006).]

78. E. E. Bykov, S. A. Lakatosh, and M. N. Preobrazhenskaya, Izv. Akad. Nauk, Ser. Khim., 55, 2069 (2006). [Russ. Chem. Bull., 55, 2149 (2006).]

79. Á. Polonka-Bálint, C. Saraceno, K. Ludányi, A. Bényei, and P. Mátyus, Synlett, 2846 (2008).

80. Á. A. Földi, K. Ludányi, A. C. Bényei, and P. Mátyus, Synlett, 2109 (2010).

81. P. Dunkel, G. Túrós, A. Bényei, K. Ludányi, and P. Mátyus, Tetrahedron, 66, 2331 (2010).

82. M. C. Haibach, I. Deb, C. K. De, and D. Seidel, J. Am. Chem. Soc., 133, 2100 (2011).

83. G. Zhou, J. Zhang, Chem. Commun., 6593 (2010).

84. A. P. Gorulya, A. V. Tverdokhlebov, A. A. Tolmachev, O. V. Shishkin, and S. V. Shishkina, Tetrahedron , 67, 1030 (2011).

85. S.-C. Zhao, X.-Z. Shu, K.-G. Ji, A.-X. Zhou, T. He, X.-Y. Liu, and Y.-M. Liang, J. Org. Chem., 76, 1941 (2011).

86. B. De Boeck, S. Jiang, Z. Janousek, and H. G. Viehe, Tetrahedron, 50, 7075 (1994).

87. B. De Boeck and H. G. Viehe, Tetrahedron, 54, 513 (1998).

88. T. G. Deryabina, N. P. Belskaia, M. I. Kodess, W. Dehaen, S. Toppet, and V. A. Bakulev, Tetrahedron Lett., 47, 1853 (2006).

89. N. P. Belskaya, V. A. Bakulev, T. G. Deryabina, J. O. Subbotina, M. I. Kodess, W. Dehaen, S. Toppet, K. Robeyns, and L. Van Meervelt, Tetrahedron, 65, 7662 (2009).

90. N. P. Belskaya, A. V. Koksharov, T. G. Deryabina, O. S. Eltsov, P. A. Slepukhin, and V. A. Bakulev, Izv. Akad. Nauk, Ser. Khim., 59, 816 (2010). [Russ. Chem. Bull., 59, 833 (2010).]

91. K. Nishiwaki, T. Ogawa, and K. Matsuo, Angew. Chem., Int. Ed., 41, 484 (2002).

92. K. Nishiwaki, T. Ogawa, K.-I. Tagami, G. Tanabe, O. Muraoka, and K. Matsuo, Tetrahedron, 62, 10854 (2006).

93. K. Nishiwaki, T. Ogawa, K. Shigeta, K. Takahashi, and K. Matsuo, Tetrahedron, 62, 7034 (2006).

94. K. Nishiwaki, A. Okamoto, K. Matsuo, Y. Hayase, S. Masaki, R. Hasegawa, and K. Ohba, Bioorg. Med. Chem., 15, 1341 (2007).

95. X. Gao, V. Gaddam, E. Altenhofer, R. R. Tata, Z. Cai, N. Yongpruksa, A. K. Garimallaprabhakaran, and M. Harmata, Angew. Chem., Int. Ed., 51, 7016 (2012).

96. R. Reinhard, M. Glaser, R. Neumann, and G. Maas, J. Org. Chem., 62, 7744 (1997).

97. G. Maas, B. Manz, T. Mayer, and U. Werz, Tetrahedron, 55, 1309 (1999).

98. M. C. R. Ruiz and A. Vasella, Helv. Chim. Acta, 94, 785 (2011).

99. I. D. Jurberg, B. Peng, E. Wöstefeld, M. Wasserloos, and N. Maulide, Angew. Chem., Int. Ed., 51, 1950 (2012).

100. C. Zhang, S. Murarka, and D. Seidel, J. Org. Chem., 74, 419 (2009).

101. C. Zhang, C. K. De, R. Mal, and D. Seidel, J. Am. Chem. Soc., 130, 416 (2008).

102. Y.-P. He, Y.-L. Du, S.-W. Luo, and L.-Z. Gong, Tetrahedron Lett., 52, 7064 (2011).

103. S. J. Mahoney and E. Fillion, Chem.-Eur. J., 18, 68 (2012). 
104. S. V. Ryabukhin, A. S. Plaskon, D. M. Volochnyuk, A. N. Shivanyuk, and A. A. Tolmachev, J. Org. Chem., 72, 7417 (2007).

105. X. Che, L. Zheng, Q. Dang, and X. Bai, Synlett, 2373 (2008).

106. N. P. Belskaia, T. G. Deryabina, A. V. Koksharov, M. I. Kodess, W. Dehaen, A. T. Lebedev, and V. A. Bakulev, Tetrahedron Lett., 48, 9128 (2007).

107. N. P. Belskaya, A. V. Koksharov, T. G. Deryabina, and V. A. Bakulev, Khim. Geterotsikl. Soedin., 1427 (2010). [Chem. Heterocycl. Compd., 46, 1156 (2010)].

108. N. K. Pahadi, M. Paley, R. Jana, S. R. Waetzig, and J. A. Tunge, J. Am. Chem. Soc., 131, 16626 (2009).

109. I. Deb, D. Das and D. Seidel, Org. Lett., 13, 812 (2011).

110. X. Xue, A. Yu, Y. Cai, and J.-P. Cheng, Org. Lett., 13, 6054 (2011).

111. T. V. Glukhareva, Yu. Yu. Morzherin, and V. S. Mokrushin, Khim. Geterotsikl. Soedin., 114 (2000). [Chem. Heterocycl. Compd., 36, 107 (2000)].

112. C. W. Rees and S. C. Tsoi, Chem. Commun., 415 (2000). 